\title{
Inflammation and Oxidative Stress in an Obese State and the Protective Effects of Gallic Acid
}

\author{
Phiwayinkosi V. Dludla ${ }^{1,2, *}$, Bongani B. Nkambule ${ }^{3}$, Babalwa Jack ${ }^{2}$, Zibusiso Mkandla ${ }^{3}$, \\ Tinashe Mutize ${ }^{3}$, Sonia Silvestri ${ }^{1}$, Patrick Orlando ${ }^{1}$, Luca Tiano ${ }^{1}$, Johan Louw ${ }^{2,4}$ and \\ Sithandiwe E. Mazibuko-Mbeje 2,5 (i) \\ 1 Department of Life and Environmental Sciences, Polytechnic University of Marche, 60131 Ancona, Italy; \\ s.silvestri@univpm.it (S.S.); p.orlando@univpm.it (P.O.); 1.tiano@staff.univpm.it (L.T.) \\ 2 Biomedical Research and Innovation Platform, South African Medical Research Council, Tygerberg 7505, \\ South Africa; babalwa.jack@mrc.ac.za (B.J.); johan.louw@mrc.ac.za (J.L.); \\ sithandiwe.mazibuko@mrc.ac.za (S.E.M.-M.) \\ 3 School of Laboratory Medicine and Medical Sciences, College of Health Sciences, University of \\ KwaZulu-Natal, Durban 4000, South Africa; nkambuleb@ukzn.ac.za (B.B.N.); \\ 217063126@stu.ukzn.ac.za (Z.M.); 217063119@stu.ukzn.ac.za (T.M.) \\ 4 Department of Biochemistry and Microbiology, University of Zululand, KwaDlangezwa 3886, South Africa \\ 5 Division of Medical Physiology, Faculty of Health Sciences, Stellenbosch University, Tygerberg 7505, \\ South Africa \\ * Correspondence: pdludla@mrc.ac.za; Tel.: +27-021-938-0333
}

Received: 15 October 2018; Accepted: 17 November 2018; Published: 21 December 2018

\begin{abstract}
Metabolic complications in an obese state can be aggravated by an abnormal inflammatory response and enhanced production of reactive oxygen species. Pro-inflammatory response is known to be associated with the formation of toxic reactive oxygen species and subsequent generation of oxidative stress. Indeed, adipocytes from obese individuals display an altered adipokine profile, with upregulated expression and secretion of pro-inflammatory cytokines such as tumor necrosis factor alpha (TNF- $\alpha$ ) and interleukin (IL-6). Interestingly, natural compounds, including phenolic enriched foods are increasingly explored for their ameliorative effects against various metabolic diseases. Of interest is gallic acid, a trihydroxybenzoic acid that has progressively demonstrated robust anti-obesity capabilities in various experimental models. In addition to reducing excessive lipid storage in obese subjects, gallic acid has been shown to specifically target the adipose tissue to suppress lipogenesis, improve insulin signaling, and concomitantly combat raised pro-inflammatory response and oxidative stress. This review will revise mechanisms involved in the pathophysiological effects of inflammation and oxidative stress in an obese state. To better inform on its therapeutic potential and improvement of human health, available evidence reporting on the anti-obesity properties of gallic acid and its derivatives will be discussed, with emphases on its modulatory effect on molecular mechanisms involved in insulin signaling, inflammation and oxidative stress.
\end{abstract}

Keywords: obesity; insulin resistance; inflammation; oxidative stress; gallic acid; therapeutic target

\section{Introduction}

Global estimates show that more than 1.9 billion adults are overweight, while over 600 million of these individuals are classified as obese [1]. The rising trend in the incidence of overweight and obesity is not only limited to developed countries as factors such as urbanization and unhealthy lifestyle, which contribute to its significant rise are also prominent in developing nations [1]. In fact, sub-Saharan women are far more likely to be obese than men, which further affects pregnancy and maternal health [1]. This can translate to complications and adverse effects on infant health, as previously 
hypothesized [2]. Visceral obesity is associated with the development of chronic metabolic diseases including insulin resistance, type 2 diabetes (T2D), and cardiovascular disease [3]. The mechanism linking obesity to these comorbidities has not been fully elucidated. However, a growing body of knowledge suggests that a possible convergence of an inflammatory state, which results in chronic inflammation and oxidative stress that is localized within an adipose tissue (Figure 1). Adipose tissue inflammation plays a crucial role in promulgating obesity-related metabolic complications including the development of insulin resistance [4,5]. An imbalance between energy intake and expenditure results in adipose tissue expansion due to excessive lipogenesis in adipose tissues [6].

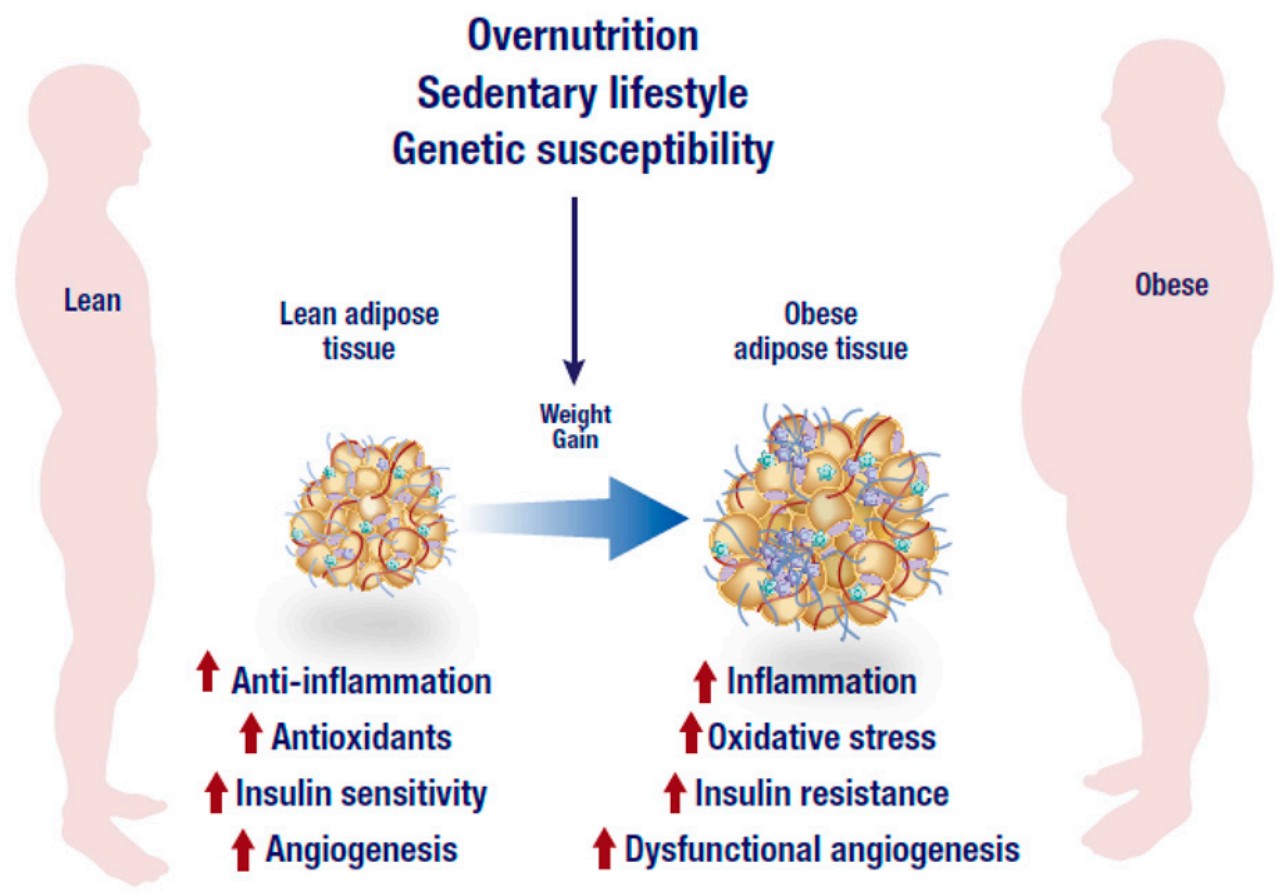

Figure 1. Overnutrition, sedentary lifestyle and genetic susceptibility are the leading factors associated with the development of obesity. In addition to dysfunctional angiogenesis, an obese state is characterized by an abnormal inflammatory response, low antioxidant capacity and reduced insulin sensitivity that may eventually lead to the generation of inflammation, oxidative stress and insulin resistance. The figure was modified from the following website, https:/ / mexicobariatriccenter.com/ improve-adipose-tissue-function/.

Adipose tissue is regarded as an endocrine organ that plays a pivotal role in the development of obesity. As excessive fat accumulation in the adipose tissue is associated with weight gain [6]. Over the years, different kinds of adipocytes have been characterized and these include beige, white, and brown which can occur in diverse proportions within individual depots, and their presence has been associated with mixed health outcomes. For example, while excessive storage of white adipose tissue is linked to detrimental effects through its aberrant secretion of pro-inflammatory cytokines, brown adipose tissue is unique for containing abundant mitochondria that are essential for improving cellular respiration and increasing adaptive thermogenesis [7,8]. Adipocytes secrete various endocrine factors such as adiponectin, estrogen, leptin, and an array of cytokines. The type of cytokines released, depend on the systemic or intracellular levels that may modulate various cell signals that can either prevent or exacerbate metabolic complications [8]. Some of the prominent mechanisms that are modulated by various endocrine factors in an obese state include insulin signaling, adipogenesis, pre-adipocyte proliferation and differentiation, and the regulation of mitochondrial energy dissipation through the modulation of lipid metabolism. For this reason, systemic or intracellular control of these factors has been an ideal therapeutic target aimed at preventing obesity or ameliorating its associated complications. 
The use of natural products as therapeutic agents in preventing metabolic disease has become popular. Despite the fact that medicinal plants have been used for centuries to combat various ailments [9], it is only in the past few decades that we have seen a rapid rise in studies reporting on the metabolic disease preventative capacity of several plant bioactive compounds or naturally derived products, as reviewed elsewhere [10]. For example, the health benefits of plant phenolics are well established, which may be attributed to their known antioxidant, anti-inflammatory, signal transducing and other biological capabilities [10-13]. Such plant phenolics include gallic acid, a trihydroxybenzoic acid found in a variety of foods and herbs that are increasingly studied for its biological activities [14-17]. Certainly, there has been an increase in the experimental data evaluating the ameliorative effects of gallic acid on metabolic diseases, including obesity [17-22]. Furthermore, several reviews focusing on the therapeutic potential of gallic acid have also been published. Briefly, in 2013, Locatelli et al. [23] focused on alkyl esters of gallic acid as anticancer agents. In 2015, Badhani et al. [24] gave an overview of the therapeutic and industrial applications of gallic acid, mostly focusing on its antioxidant properties. In the same year, Choubey et al. [25] summarized evidence of patents reporting on anticarcinogenic, antimicrobial, antimutagenic, antiangiogenic and anti-inflammatory properties of gallic acid and its ester derivatives. In 2016, Fernandes and Salgado reviewed analytical methods for the determination and quantification of gallic acid, including emphasizing the advantages and limitations of each technique [26], while Nayeem et al. [27] gave a general overview on the therapeutic potential of gallic acid. In 2017, Kosuru et al. [28] discussed literature summarizing the effects of gallic acid and gallates in human health and disease, with specific emphasizes on mitochondria as the target site.

Although the aforementioned reviews have provided an important platform that improves our understanding on the therapeutic potential of gallic acid and its derivatives, none have appraised literature on the anti-obesity properties of this phenolic acid. The current review systematically extracted the available primary findings and critically assessed these studies to better inform on the anti-obesity properties of gallic acid by modifying an already published protocol [29]. For data extraction, a search on the association between gallic acid and obesity was conducted using major search engines and databases such as PubMed/Medline, EMBASE, Cochrane Library Databases and Google Scholar. The search was done from inception until end of June 2018, grey literature including abstract proceedings and pre-prints were also included. There were no language restrictions applied, while review articles were assessed for primary findings. Medical subject heading (MeSH) terms such as gallic acid and its derivatives, metabolic syndrome, obesity, inflammation, oxidative stress, and apoptosis, including corresponding synonyms and associated terms for each item were used. Plants and extracts not reported to contain gallic acid, or that through background check had not been characterized to contain gallic acid or its derivatives, were excluded from this study. Furthermore, pathophysiological mechanisms involved in an obese state, especially the detrimental effects of enhanced pro-inflammatory response and oxidative stress are discussed to highlight the anti-obesity potential of gallic acid.

\section{Inflammation and Insulin Resistance in Adipose Tissue}

Generally, it is well accepted that adipose tissue expansion in an obese state is accompanied by elevated inflammation and infiltration of inflammatory macrophages into adipose tissue. As displayed in Figure 1, increased abdominal adipose tissue accelerates the production of pro-inflammatory cytokines which are associated with the degree of metabolic dysfunction [30]. Adipose tissue is highly vascularized and angiogenic [31]. This ensures adequate neovascularisation that is required for oxygen and nutrient supply of the expanding tissue. An imbalance between expansion and vascularization results in hypoxia, which promotes adipose tissue inflammation. Through the reduction of angiogenetic growth components such as vascular endothelial growth factor (VEGF) during hypoxia, several processes including the formation of new blood cells in the adipose tissue are hindered [32,33]. Adipose tissue expansion is usually accompanied by reduced vascularization, and this process may 
exacerbate metabolic disease pathogenesis [32,33]. In fact, effective modulation of angiogenesis and vasculatures in adipose tissue has been proposed to be a viable mechanism to reverse obesity associated complications [34]. However, uncontrolled adipose tissue expansion in an obese state is also associated with dysfunctional lipid metabolism including excessive lipolysis (Figure 2), which in turn leads to increased production and secretion of free fatty acids (FFAs) into the circulation [35]. Inflammation localized in adipocytes, alters their adipokine profile, which may shift towards a pro-inflammatory phenotype that is accompanied by a high expression and secretion of pro-inflammatory cytokines such as tumor necrosis factor-alpha (TNF- $\alpha$ ), interleukin-6 (IL-6) and other mediators of inflammation [36]. TNF- $\alpha$ is one of the earliest pro-inflammatory cytokines identified and its abnormally elevated levels are associated with obesity, insulin resistance and T2D. For example, knockout of TNF- $\alpha$ in diet-induced obese or leptin deficient $(o b / o b)$ mice was linked with increased insulin sensitivity [37,38]. Such effects have also been confirmed in human subjects and leptin resistant mice where elevated lipids or TNF- $\alpha$ have been associated with obesity, insulin resistance and cardiovascular complications [39-41], suggesting that adipose tissue inflammation and obesity are implicated in the development of T2D.

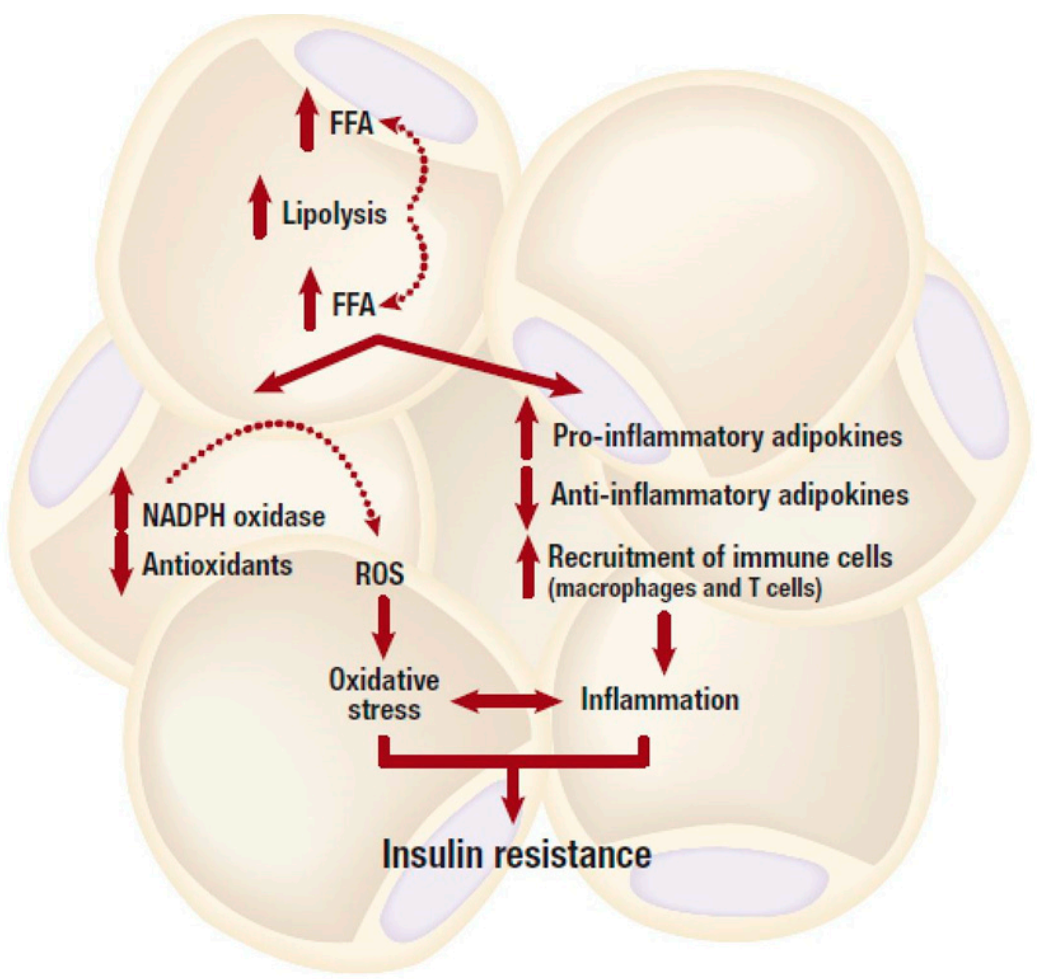

Figure 2. An obese state is associated with dysfunctional lipid metabolism including excessive lipolysis, which in turn leads to increased production and secretion of free fatty acids (FFAs). Elevated FFA levels can cause an abnormal pro-inflammatory response, and subsequent development of insulin resistance. Whereas, depleted intracellular antioxidant systems in the adipose tissue, mainly due to increased production of reactive oxygen species (ROS) can generate oxidative stress, and this can further lead to the development of insulin resistance. NADPH, nicotinamide adenine dinucleotide phosphate.

Macrophage infiltration into the adipose tissue can also initiate chronic immune activation, leading to metabolic dysregulation and an increased risk of cardiovascular disease [42,43]. Several factors, either derived from adipocytes or endothelial cells within adipose tissue, are thought to initiate the recruitment of macrophages into adipose tissue. This leads to the infiltration of some immune cells, such as neutrophils and T cells which subsequently induces hypoxia and adipocyte cell death [38]. The order of immune cell recruitment remains unclear however in obesity, macrophages represent more than half of leukocyte population present in visceral and subcutaneous adipose tissue [30]. Some studies have demonstrated a direct association between elevated macrophages found in visceral 
white adipose tissue and increased body mass index [44]. In animal models of diet induced obesity, macrophages constitute around 50\% of all adipose tissue cells [30], whereas in lean mice and humans, adipose tissue cells comprise of only $5 \%$ macrophages [30]. In fact, inhibiting macrophage infiltration by blocking the monocyte chemoattractant 1 (MCP-1) ameliorates insulin resistance [45].

Adipokines such as adiponectin have been demonstrated to inhibit macrophage function $[46,47]$ and leptin has been shown to promote inflammation by inducing $\mathrm{T}$ lymphocyte activation and proliferation [48]. Products of lipolysis such as FFAs activate T lymphocytes which result in increased adipose mass and adipose tissue inflammation. Interestingly, T-helper cell $17\left(\mathrm{~T}_{\mathrm{H}} 17\right)$ cytokine levels have been connected with inflammation in obese people living with T2D [49]. On the other side, it has been found that hyperglycemia induces the production of TNF- $\alpha$ through the down-regulation of monocyte cell surface CD33, a transmembrane receptor expressed by monocytes in peripheral blood [50]. CD33 plays a crucial role in inhibiting cytokine production, and the reduction of CD33 expression in monocytes and lymphocytes is associated with increased production of inflammatory cytokines such as TNF- $\alpha$ and IL-1 [50,51]. $\mathrm{T}_{\mathrm{H}} 17$ lymphocytes secrete IL-17, which triggers the nuclear factor kappa-light-chain-enhancer of activated B cells (NF- $k B$ ) leading to the activation of $B$ lymphocytes [52].

In relation to insulin signaling (Figure 2), high levels of FFA and pro-inflammatory adipokines have been reported to induce insulin resistance in insulin sensitive cells such as adipocytes, hepatocytes and cardiomyocytes $[35,53,54]$. This is mediated by inhibiting the insulin signaling pathway through the activation of intracellular stress kinases such as the inhibitor $\kappa B$ kinase (IKK) complex and c-JUN $\mathrm{NH}_{2}$-terminal kinase (JNK) $[55,56]$. Subsequently, this can induce either inflammation or the serine phosphorylation of insulin receptor substrate 1 (IRS-1), leading to impaired downstream insulin signaling $[55,56]$. Chronic levels of FFAs and pro-inflammatory cytokines can also activate the inducible nitric oxide synthase (iNOS), which prompts nitric oxide (NO) production thereby causing a subsequent degradation of IRS-1 [57]. Furthermore, NO also blocks phosphatidylinositol 3-kinase (PI3K)/protein kinase B (Akt) activity by inducing s-nitrosylation of Akt [58]. The excessive production of saturated FFAs increases the accumulation of toxic lipid metabolites such as ceramides, diacylglycerols, linoleic acid, or phosphatidic acid, and activate phosphokinase C (PKC) [53]. Phosphorylation of this kinase enzyme induces downstream activation of IKK and JNK, and this may lead to a subsequent interruption of the insulin signaling and generation of oxidative stress [53]. This has been demonstrated in experimental models either suppressing or overexpressing JNK [59].

\section{Oxidative Stress in Adipose Tissue}

In addition to driving an enhanced pro-inflammatory response, adipose tissue expansion during the progression of obesity can result in excess production of toxic radical species that can cause generation of oxidative stress. Although mechanisms involved in this process are complex, a strong correlation between reduction of the vasculature (vessel rarefaction) and generation of oxidative stress through reactive oxygen species (ROS) has been reviewed [60,61]. Besides their well-known detrimental actions, ROS are physiologically important for acting as second messengers in cell signaling and they also play a pivotal role in cellular homeostasis [62]. The term ROS encompasses free radical species, including hydroxyl $(\cdot \mathrm{OH})$, superoxide $\left(\mathrm{O}_{2}{ }^{\bullet}{ }^{-}\right)$, and hydrogen peroxide $\left(\mathrm{H}_{2} \mathrm{O}_{2}\right)$. Oxidative stress is a consequence of an imbalance between ROS production and scavenging, while chronic or sustained oxidative stress may be associated with cellular damage by oxidizing cellular constituents such as proteins, lipids and DNA $[62,63]$. In adipose tissue, obesity can induce oxidative stress mainly via catalytic activity of nicotinamide adenine dinucleotide phosphate (NADPH) oxidase (NOX) enzyme or through dysfunctional mitochondrial oxidative phosphorylation $[63,64]$. NOX remains the major route for ROS production in adipocytes [65]. This plasma membrane-bound enzyme contributes to ROS production by transferring electrons from NADPH to oxygen, thus generating $\mathrm{O}_{2} \bullet-$, which is further converted to $\mathrm{H}_{2} \mathrm{O}_{2}$ by superoxide dismutase [65]. NOX exists in seven different isoforms that are widely expressed in various tissue. Notably, NOX4 is predominantly expressed in murine and human 
adipocytes [65]. In obese mice, the mRNA expression levels of NOX subunits were solely increased in adipose tissue and this was accompanied by increased ROS production in adipose tissue [66]. While adipose-specific deletion of NOX4 attenuated adipose tissue inflammation and the early onset of insulin resistance in diet-induced obese mice [67], suggesting that NOX4 derived oxidative stress and ROS production plays a role in the development of insulin resistance in adipose tissue. High levels of FFAs and glucose, which are abundant in obesity seem to contribute to NOX activation and ROS production (Figure 2). In cultured 3T3-L1 adipocytes, high levels of FFAs and glucose increased ROS production via NOX activation $[66,68]$. In addition, treatment with NOX inhibitors or the silencing of NOX4 appeared to ameliorate this effect by decreasing ROS generation $[66,68]$.

The mitochondrial electron transport chain is among the main sites for ROS production in most mammalian cells that mainly takes place during oxidative phosphorylation [69]. Several studies have shown that mitochondrial-derived ROS production is associated with the late stages of obesity as compared to NOX-derived ROS production, which is associated with the early stages of obesity [64]. In a morbidly obese state, adipocytes utilize FFAs derived from triglyceride stores via excessive lipolysis for energy production, as a result of glucose deprivation due to insulin resistance [64]. Excessive FFAs lead to an overflow of electrons in the electron transport chain during oxidative phosphorylation, resulting in their leakage and generation of $\mathrm{O}_{2}{ }^{-}-$followed by the production of other ROS molecules [64,70]. Excess production of mitochondrial derived ROS is associated with aggravation of inflammation and development of insulin resistance in adipocytes through the activation of the NF- $\mathrm{KB}$ [71]. The phenomenon of enhanced pro-inflammatory response and oxidative stress in an obese state contributes significantly to the development of other metabolic complications such as T2D, cardiovascular diseases and certain types of cancers [3,72]. Hence the increased focus on developing therapeutic agents that target inflammation and oxidative stress with the aim of preventing these diseases [72-75]. In addition to well-established antidiabetic drugs such as metformin and insulin, literature on the anti-inflammatory and antioxidant effects of some other agents like salsalate, diacerein and chloroquine has been previously reviewed [76]. Briefly, in addition to their beneficial effects in maintaining blood glucose levels in diabetic patients, most of these drugs prompt diverse effects ranging from reducing circulating oxidized low-density lipoprotein-induced pro-inflammatory responses in monocytes and macrophages, to inhibiting IL-1 $\beta$, TNF- $\alpha$, and NF- $\mathrm{kB}$ levels in blood and different body tissues. However, limitations, such as scanty studies on human subjects, as well as controversial and inconclusive evidence, indicate the need to investigate alternative therapies. Interestingly, increasing research shows that gallic acid can ameliorate inflammation and oxidative stress, through improvement of mitochondrial biogenesis, among discussed mechanisms [28].

\section{A Brief Overview of the Classification, Occurrence, and Bioavailability of Gallic Acid}

Gallic acid (PubChem CID: 370), is a 3,4,5-trihydroxybenzoic acid with the molecular formula $\mathrm{C}_{7} \mathrm{H}_{6} \mathrm{O}_{5}$ (MW $170.12 \mathrm{~g} / \mathrm{mol}$ ) that is abundantly found in gallnuts, sumac, witch hazel, tea leaves, oak bark, and other plants [77]. Gallic acid belongs to a distinct group of naturally occurring compounds known as phenolic acids, and is conventionally produced by hydrolysis of tannic acid. This class of compounds is unique for containing a phenol ring that possesses at least one carboxylic acid functionality (Figure 3). Phenolic acids are generally subclassified into benzoic acids comprising seven carbon atoms (C6-C1) and cinnamic acids with nine carbon atoms (C6-C3) [12]. However, gallic acid exist predominantly as hydroxybenzoic acids $[77,78]$ and occurs in different forms of esters and salts, including epigallocatechin gallate (PubChem CID: 65064) [79], ethyl gallate (PubChem CID: 13250) [80], gallocatechin gallate (PubChem CID: 199472) [81], methyl gallate (PubChem CID: 7428) [82], propyl gallate (PubChem CID: 4947) [83], theaflavin-3-gallate (PubChem CID: 169167) [84] and others (Figure 3).

Despite their wide distribution, the health effects of phenolic acids, including gallic acid, can be affected by several factors including poor stability as well as restricted bioavailability and absorption $[85,86]$. It is mostly accepted that bioavailability can vary among different phenolic acids, 
and the dietary abundance of a specific compound does not necessarily translate to best bioavailability profile. Although available experimental studies in animals and humans have demonstrated that gallic acid can be absorbed in the body [85,87-89], its effectiveness can be hindered due to rapid metabolism and elimination $[85,86]$. Furthermore, like most natural products, additional studies specific to determining food species with properties that elevate gallic acid bioavailability, and knowing how much of certain foods one need to consume to have the beneficial dosage of this phenolic acid in plasma are required. Nonetheless, after oral administration, it is estimated that approximately $70 \%$ of gallic acid is absorbed and then excreted in the urine as 4-O-methylgallic acid [89,90]. Most importantly, several methods have been tested in efforts to improve the bioavailability of gallic acid in the circulation and target tissues. These include repeated dosing and the use of structural analogs or derivative compounds of gallic acid, which significantly improves the plasma levels of this phenolic acid [91]. Similarly, other researchers showed that using other systems such as phospholipid complexation or microencapsulation can enhance the therapeutic efficacy of gallic acid through increasing absorption and bioavailability in serum [92]. Recently, it has been shown that gallic acid significantly enhanced the bioavailability of diltiazem, a calcium channel blocker widely used to treat hypertension, leading to the inhibition of both cytochrome P450 isozyme (CYP3A)-mediated metabolism and P-glycoprotein-mediated efflux in the intestine and/or liver [87]. This result is of interest since the process of absorption, distribution, metabolism, and excretion of different agents can be affected by co-treatment with other drugs, as well as various physiological and pathological changes. A recent study showed that pharmacokinetic process of gallic acid is different between normal and rats subjected to myocardial infarction [93]. Suggesting that additional studies are required to assess the pharmacokinetic profile of herbal preparations or dietary nutrition containing gallic acid in different pathological conditions, as well as its co-treatment with currently used agents. Nonetheless, experimental data reporting on the ameliorative effect of gallic acid against metabolic complications has increased over the years.<smiles>O=C(O)c1cc(O)c(O)c(O)c1</smiles><smiles>O=C(OC1Cc2c(O)cc(O)cc2OC1c1cc(O)c(O)c(O)c1)c1cc(O)c(O)c(O)c1</smiles><smiles>O=C(OC1Cc2c(O)cc(O)cc2OC1c1cc(O)c(O)c(O)c1)c1cc(O)c(O)c(O)c1</smiles>

Epigallocatechin gallate<smiles>CCOC(=O)c1cc(O)c(O)c(O)c1</smiles><smiles>COC(=O)c1cc(O)c(O)c(O)c1</smiles><smiles>CCCOC(=O)c1cc(O)c(O)c(O)c1</smiles>

Figure 3. Chemical structures of gallic acid and its derivative compounds, including epigallocatechin gallate, ethyl gallate, gallocatechin gallate, methyl gallate, propyl gallate, theaflavin-3-gallate that are increasingly studied for their anti-obesity properties. 


\section{Experimental Models Investigating the Anti-Obesity Effects of Gallic Acid}

Currently, various experimental models are being explored to investigate the anti-obesity properties of pharmacological compounds, including natural products and plant-derived extracts [94]. Pre-clinical models of obesity are presently divided into different categories, the major ones being based on genetic mutations or manipulation, while others focus on intact animals exposed to obesogenic environments such as being maintained on high-fat diets [94]. Indeed, it was evident that the majority of studies presented in Tables 1-4 investigated the therapeutic effect of gallic acid or extracts rich in this phenol through the use of fat pads from high fat diet (HFD) fed rats and mice. The only reported transgenic model of obesity used were ddY mice [95], a mouse model known to be susceptible to obese characteristics, including cholesterol, hyperglycemia and hypertriglyceridemia in response to obesogenic diet [95]. Besides the use of cultured 3T3-L1 adipocytes [21,96,97], other models that were widely used to test the anti-obesity properties of gallic acid were in vitro experiments that inhibit various enzymes involved in fat breakdown and metabolism [98,99]. Lipase inhibitors are known to bind to lipase enzymes in the intestine, thus blocking hydrolysis of dietary triglycerides into monoglycerides and FFAs [100]. Recently, in silico methods, such as molecular docking, have also become popular. Such systems have been used to assess the inhibitory effect of gallic acid against lipases [101,102]. 
Table 1. Overview of studies reporting on the ameliorative effect of gallic acid against obesity-associated complications.

\begin{tabular}{|c|c|c|c|}
\hline Author, Year & Experimental Model, Dose Used, and Intervention Period & Comparative/Combination Therapy & Experimental Outcome and Proposed Mechanism \\
\hline Strobel et al., 2005 [103] & $\begin{array}{l}\text { Adipocytes from epididymal fat pads from male Wistar rats } \\
\text { treated with gallic acid at } 0.1-100 \mu \mathrm{M}\end{array}$ & $\begin{array}{l}\text { Catechin, myricetin and quercetin were used at } \\
0.1-100 \mu \mathrm{M} \text {, together with } 1 \mu \mathrm{M} \text { insulin for } 30 \mathrm{~s}\end{array}$ & $\begin{array}{l}\text { All compounds inhibited glucose uptake through } \\
\text { interfering with the function of glucose transporter } \\
\text { (GLUT) } 4\end{array}$ \\
\hline Hsu et al., 2006 [104] & $\begin{array}{l}\text { 3T3-L1 pre-adipocytes treated with gallic acid at } 43.3 \mu \mathrm{M} \text { for } 24 \text {, } \\
\qquad 48 \text { and } 72 \mathrm{~h}\end{array}$ & $\begin{array}{l}\text { Chlorogenic acid, } o \text {-coumaric acid and } \\
m \text {-coumaric acid were used at } 72.3,48.2, \\
\text { and } 49.2 \mu \mathrm{M} \text {, respectively, for } 24,48 \text {, and } 72 \mathrm{~h}\end{array}$ & $\begin{array}{l}\text { All phenolic acids, at varying degree, improved the } \\
\text { antioxidant status and inhibited proliferation }\end{array}$ \\
\hline Hsu et al., 2007 [21] & $\begin{array}{l}\text { 3T3-L1 pre-adipocytes treated with } 0.1-250 \mu \mathrm{M} \text { gallic acid for } \\
\qquad 24,48 \text { and } 72 \mathrm{~h}\end{array}$ & None & $\begin{array}{c}\text { Inhibited proliferation by blocking histone deacetylase } \\
\text { activity. Further enhanced protein expression of fatty acid } \\
\text { synthase (FAS), FAS ligand (FasL), as well as tumor protein } \\
53 \text { (p53) and activated caspase } 3 / 9\end{array}$ \\
\hline Hsu and Yen, 2007 [105] & $\begin{array}{l}\text { High fat diet (HFD) fed male Wistar rats received } 50 \text { and } 100 \\
\text { mg/kg body weight of gallic acid for } 10 \text { weeks }\end{array}$ & None & $\begin{array}{c}\text { Reduced body weight, organ weight of the liver and } \\
\text { adipose tissue weights. Further improved hepatic } \\
\text { glutathione levels }\end{array}$ \\
\hline Jang et al., 2008 [106] & $\begin{array}{l}\text { HFD fed female C57BL/6 Cr Slc mice treated with gallic acid, } \\
\text { at } 1 \% \text { of diet for } 7 \text { weeks }\end{array}$ & $\begin{array}{l}\text { Linoleic acid and a mixture of gallic acid and } \\
\text { linoleic acid were mixed with diet }\end{array}$ & $\begin{array}{l}\text { All compounds showed hypolipidemic effects through } \\
\text { reducing body weights and hepatic oil droplets, } \\
\text { while improving lipid profiles }\end{array}$ \\
\hline Booth et al., 2010 [107] & $\begin{array}{l}\text { Male and female BR VAF/Plus rats given a combination of } \\
\text { rhubarb, astragalus, red sage, ginger, and turmeric, together } \\
\text { with gallic acid at 215, } 430 \text { and } 860 \mathrm{mg} / \mathrm{kg} \text { body weight for } \\
20 \text { days }\end{array}$ & None & Significantly reduced body weights \\
\hline Punithavathi et al., 2011 [108] & $\begin{array}{l}\text { Streptozotocin-induced diabetic male Wistar rats treated with } \\
\text { gallic acid at } 10 \text { and } 20 \mathrm{mg} / \mathrm{kg} \text { body weight for } 21 \text { days }\end{array}$ & None & $\begin{array}{c}\text { Reduced blood glucose and hepatic lipid peroxidation } \\
\text { products, glycoprotein components, lipids, and the activity } \\
\text { of } \beta \text {-Hydroxy } \beta \text {-methylglutaryl-CoA (HMG-CoA) } \\
\text { reductase. }\end{array}$ \\
\hline Oi et al., 2012 [95] & $\begin{array}{l}\text { HFD fed female ddY mice treated with gallic acid at } 15, \\
45 \mathrm{mg} / \mathrm{kg} \text { body weight for } 12 \text { weeks }\end{array}$ & $\begin{array}{l}\text { Black tea extract was used at } 50,100 \mathrm{mg} / \mathrm{kg} \\
\text { body weight for } 12 \text { weeks }\end{array}$ & $\begin{array}{l}\text { Reduced body weights, as well as inhibited pancreatic } \\
\text { lipase activity }\end{array}$ \\
\hline Bak et al., 2013 [109] & $\begin{array}{l}\text { HFD fed male C57BL } / 6 \text { mice treated with gallic acid at } \\
10 \mathrm{mg} / \mathrm{kg} \text { body weight for } 2 \text { weeks }\end{array}$ & None & $\begin{array}{l}\text { Reduction in adipocyte size was associated with } \\
\text { upregulation of peroxisome proliferator-activated receptor } \\
\text { gamma (PPAR) } \gamma \text { expression and activation of protein } \\
\text { kinase B (Akt) signaling pathway }\end{array}$ \\
\hline Ou et al., 2013 [110] & $\begin{array}{l}\text { Oleic acid-induced proliferation of vascular smooth muscle } \\
\text { cells treated with gallic acid at } 10-30 \mu \mathrm{M} \text { for } 48 \mathrm{~h}\end{array}$ & None & $\begin{array}{l}\text { Displayed anti-atherogenic effects, inhibited fatty acid } \\
\text { synthase (FAS), blocked endothelial nitric oxide synthase } \\
\text { and activated 5' adenosine monophosphate-activated } \\
\text { protein kinase (AMPK) }\end{array}$ \\
\hline Chao et al., 2014 [18] & $\begin{array}{l}\text { HFD fed male C57BL } / 6 \text { mice treated with gallic acid at } 50 \text { and } \\
\qquad 100 \mathrm{mg} / \mathrm{kg} \text { body weight for } 16 \text { weeks }\end{array}$ & None & $\begin{array}{l}\text { Partially reversed metabolic disturbances, including lipid } \\
\text { and glucose metabolism, amino acids metabolism, choline } \\
\text { metabolism and gut-microbiota-associated metabolism }\end{array}$ \\
\hline
\end{tabular}


Table 1. Cont

\begin{tabular}{|c|c|c|c|}
\hline Author, Year & Experimental Model, Dose Used, and Intervention Period & Comparative/Combination Therapy & Experimental Outcome and Proposed Mechanism \\
\hline Doan et al., 2014 [111] & $\begin{array}{l}\text { HFD fed male C57BL/ } 6 \text { mice treated with gallic acid at } 10 \\
\mathrm{mg} / \mathrm{kg} \text { of body weight for } 9 \text { weeks }\end{array}$ & None & $\begin{array}{l}\text { Induced browning of adipose tissue through activation of } \\
\text { AMPK/Nicotinamide adenine dinucleotide } \\
\text { (NAD)-dependent deacetylase sirtuin-1 } \\
\text { (SIRT1)/peroxisome proliferator activated receptor gamma } \\
\text { coactivator } 1 \text { alpha (PGC1 } \alpha \text { ) pathway. Also regulated } \\
\text { uncoupling protein 1 }\end{array}$ \\
\hline Gandhi et al., 2014 [20] & $\begin{array}{l}\text { HFD fed and streptozotocin induced diabetic male Wistar rats } \\
\text { treated with gallic acid at } 20 \mathrm{mg} / \mathrm{kg} \text { body weight for } 28 \text { days }\end{array}$ & $\begin{array}{l}\text { Pioglitazone was used at } 10 \mathrm{mg} / \mathrm{kg} \text { body weight } \\
\text { for } 28 \text { days }\end{array}$ & $\begin{array}{l}\text { Improved insulin sensitivity through translocation and } \\
\text { activation of GLUT4 in phosphatidylinositol -3-kinase } \\
\text { (PI3K)/p-Akt dependent pathway. Furthermore, } \\
\text { it moderately enhanced PPAR } \gamma \text { expression }\end{array}$ \\
\hline \multirow[t]{2}{*}{ Pandey et al., 2014 [17] } & $\begin{array}{c}\text { HFD induced male C57BL } / 6 \text { mice were treated with gallic acid } \\
\text { at } 2,4 \text { and } 8 \mathrm{mg} / \mathrm{kg} \text { body weight for } 28 \text { days }\end{array}$ & None & $\begin{array}{l}\text { Lowered serum levels of triglycerides, and low-density } \\
\text { lipoprotein, while increasing high density lipoprotein } \\
\text { concentrations }\end{array}$ \\
\hline & $\begin{array}{l}\text { 3T3-L1 adipocytes treated with gallic acid at 3.12, 6.25, 12.5, 25, } \\
\qquad 50 \text { and } 100 \mu \mathrm{M} \text { for } 48 \mathrm{~h}\end{array}$ & $\begin{array}{l}\text { Aqueous extract Labisia pumila and pyrogallol } \\
\text { were used at } 3.12-100 \mu \mathrm{M} \text { for } 48 \mathrm{~h}\end{array}$ & $\begin{array}{l}\text { Both compounds and extract showed inhibitory effect on } \\
\text { fat droplet formation and triglyceride accumulation }\end{array}$ \\
\hline Makihara et al., 2016 [16] & $\begin{array}{l}\text { 3T3-L1 adipocytes were treated with gallic acid at 10-30 } \mu \mathrm{M} \\
\text { during differentiation period }\end{array}$ & $\begin{array}{l}\text { Troglitazone was used at } 10 \mu \mathrm{M} \text {, while } \\
\text { Terminalia bellirica hot water extract was used at } \\
0.1,1.0 \text { and } 10 \text { during differentiation }\end{array}$ & $\begin{array}{c}\text { The extract and gallic acid enhanced adipocyte } \\
\text { differentiation and adiponectin secretion, partially through } \\
\text { increasing adiponectin and fatty acid binding } \\
\text { protein-4 levels }\end{array}$ \\
\hline Huang et al., 2018 [112] & $\begin{array}{l}\text { HFD fed male Wistar rats were treated with gallic acid at } 10 \text { or } \\
\qquad 30 \mathrm{mg} / \mathrm{kg} \text { body weight for } 8 \text { weeks }\end{array}$ & $\begin{array}{l}\text { Pioglitazone was used at } 30 \mathrm{mg} / \mathrm{kg} \text { body weight } \\
\text { for } 8 \text { weeks }\end{array}$ & $\begin{array}{l}\text { Decreased the perirenal adipose tissues and restored } \\
\text { expression of insulin receptor and GLUT4 in the perirenal } \\
\text { adipose tissues }\end{array}$ \\
\hline Author, Year & Experimental Model, Dose Used, and Intervention Period & Comparative/Combination Therapy & Experimental Outcome and Proposed Mechanism \\
\hline Ong et al., 1995 [113] & $\begin{array}{l}\text { Adipocytes from epididymal fat pads from male Wistar rats } \\
\text { treated with gallic acid at } 1-1000 \mu \mathrm{M} \text { for various times from } 20 \\
\qquad \min \text { to } 2 \mathrm{~h}\end{array}$ & $\begin{array}{l}\text { Tannic acid was used at } 1-1000 \mu \mathrm{M} \text { for various } \\
\text { times from } 20 \mathrm{~min} \text { to } 2 \mathrm{~h}\end{array}$ & $\begin{array}{c}\text { Tannic acid inhibited insulin stimulated lipogenesis } \\
\text { through promoting activation of insulin-receptor-associated } \\
\text { tyrosine kinase phosphorylation. Whereas, gallic acid } \\
\text { showed no effect }\end{array}$ \\
\hline Ren et al., 2006 [114] & $\begin{array}{l}\text { 3T3-L1 pre-adipocytes incubated with } \\
\text { 6-deoxytetra-O-galloyl- } \alpha \text {-D-glucopyranose, } \\
\text { tetra-O-galloyl- } \alpha \text {-D-xylopyranose and } \\
\text { 6-chloro-6-deoxy-1,2,3,4-tetra-O-galloyl- } \alpha \text {-D-glucopyranose at } \\
30 \mu \mathrm{M} \text { for } 15 \mathrm{~min}\end{array}$ & None & Improved glucose uptake \\
\hline
\end{tabular}


Table 2. Cont.

\begin{tabular}{|c|c|c|c|}
\hline Author, Year & Experimental Model, Dose Used, and Intervention Period & Comparative/Combination Therapy & Experimental Outcome and Proposed Mechanism \\
\hline Hsu and Yen, 2007 [96] & $\begin{array}{l}\text { 3T3-L1 adipocytes were treated with gallic acid at 1-250 } \mu \mathrm{M} \text { for } \\
\qquad 72 \mathrm{~h}\end{array}$ & $\begin{array}{l}o \text {-coumaric acid and rutin were used at with } \\
\qquad 1-250 \mu \mathrm{M} \text { for } 72 \mathrm{~h}\end{array}$ & $\begin{array}{l}o \text {-coumaric acid and rutin demonstrated better effect in } \\
\text { inhibiting glycerol-3-phosphate dehydrogenase activity, } \\
\text { and the expression of peroxisome proliferator activated } \\
\text { receptor (PPAR) } \gamma \text {, CAAT/enhancer-binding proteins } \\
\text { (C/EBPR) and leptin. While also upregulating } \\
\text { adiponectin levels }\end{array}$ \\
\hline Hsieh et al., 2010 [97] & $\begin{array}{l}\text { 3T3-L1 and C3H10T1/2 adipocytes treated with gallic acid at } \\
\qquad 5-10 \mu \mathrm{M} \text { for } 2 \mathrm{~h}\end{array}$ & $\begin{array}{c}\text { Compound C, n-acetyl-L-cysteine, } \\
\text { epigallocatechin gallate and other catechins, } \\
\text { such as epicatechin, epigallocatechin, and } \\
\text { epicatechin 3-gallate were used at 5-10 } \mu \mathrm{M} \text { for } \\
2 \mathrm{~h}\end{array}$ & $\begin{array}{l}\text { Epigallocatechin gallate performed better than other } \\
\text { compounds in inhibiting insulin stimulated glucose uptake } \\
\text { with mechanistic involvement of } 5^{\prime} \text { adenosine } \\
\text { monophosphate -activated protein kinase } \\
\text { (AMPK) pathways }\end{array}$ \\
\hline Totani et al., 2011 [22] & $\begin{array}{l}\text { High fat diet fed male Wistar rats treated with gallic acid at } 90 \\
\text { ppm in diet for } 12 \text { weeks }\end{array}$ & $\begin{array}{c}\text { (z)-3-(3,4,5-trihydroxybenzoyloxy) } \\
\text { propane-1,2-diyl dioleate (DOGGA) and octyl } \\
\text { gallate (OG) were both used at } 90 \mathrm{ppm} \text { in diet } \\
\text { for } 12 \text { weeks }\end{array}$ & $\begin{array}{l}\text { DOGGA showed pronounced effect than OG in reducing } \\
\text { the body weight in rats. Gallic acid showed no effect }\end{array}$ \\
\hline Sergent et al., 2012 [115] & In vitro bioassays testing epigallocatechin-3-gallate at $0.8 \mu \mathrm{M}$ & $\begin{array}{l}\text { Kaempferol and quercetin were effective at } 13.4 \\
\text { and } 21.5 \mu \mathrm{M} \text {, respectively }\end{array}$ & $\begin{array}{l}\text { Epigallocatechin-3-gallate presented pronounced pancreatic } \\
\text { lipase inhibitory effect than both kaempferol and quercetin }\end{array}$ \\
\hline Park et al., 2014 [116] & $\begin{array}{l}\text { 3T3-L1 adipocytes treated with gallic acid at 30,60 and } 90 \mu \mathrm{M} \\
\text { during differentiation period }\end{array}$ & $\begin{array}{l}\text { KMU-3, a derivative of gallic acid, was used at } 1, \\
5 \text { and } 10 \mu \mathrm{M} \text { during differentiation period }\end{array}$ & $\begin{array}{c}\text { KMU-3 outperformed gallic acid in suppressing lipid } \\
\text { accumulation in cells. Mechanistically, it inhibited } \\
\text { expressions of C/EBP-A, PPAR } \gamma \text {, and Fas, as well as some } \\
\text { pro-inflammatory markers }\end{array}$ \\
\hline Yang et al., 2015 [117] & $\begin{array}{l}\text { 3T3-L1 pre-adipocyte treated with epigallocatechin } \\
\text { 3-O-(3-O-methyl) gallate and epicatechin-3-gallate at } 20,40 \text { and } \\
\qquad 80 \mu \mathrm{g} / \mathrm{mL} \text { for } 48 \mathrm{~h}\end{array}$ & None & $\begin{array}{l}\text { Epigallocatechin 3-O-(3-O-methyl) gallate presented higher } \\
\text { activity than epicatechin-3-gallate in inhibiting } \\
\text { adipogenesis and proliferation }\end{array}$ \\
\hline Jeon et al., 2016 [118] & $\begin{array}{l}\text { 3T3-L1 adipocytes treated with methyl gallate at 25, } 50 \text { and } \\
\qquad 75 \mu \mathrm{M} \text { for } 48 \mathrm{~h}\end{array}$ & None & $\begin{array}{l}\text { Inhibited adipogenesis through stabilizing } \beta \text {-catenin } \\
\text { suppression of PPAR } \gamma \text { expression. Further stimulated } \\
\text { canonical Wnt } / \beta \text {-catenin signaling }\end{array}$ \\
\hline Ediriweera et al., 2017 [14] & MCF-7 cells treated with gallic acid at $90 \mu \mathrm{M}$ for $48 \mathrm{~h}$ & $\begin{array}{l}\text { Ascorbic acid }(6.5 \mu \mathrm{M}) \text {, catechin }(583 \mu \mathrm{M}) \text {, } \\
\text { curcumin }(3.5) \text {, epigallocatechin gallate }(7.5 \mu \mathrm{M}) \text {, } \\
\text { and quercetin }(70 \mu \mathrm{M}) \text { for } 48 \mathrm{~h}\end{array}$ & $\begin{array}{c}\text { Only quercetin, curcumin and epigallocatechin gallate } \\
\text { showed significant protective effects against leptin-induced } \\
\text { proliferation }\end{array}$ \\
\hline Zengin et al., 2017 [101] & $\begin{array}{l}\text { In vitro docking experiments assessing lipase inhibitory effect } \\
\text { of gallic acid }\end{array}$ & $\begin{array}{l}p \text {-OH-benzoic acid, catechin, epigallocatechin } \\
\text { gallate, epicatechin, and rosmarinic acid }\end{array}$ & $\begin{array}{l}\text { Epigallogatechin gallate and rosmarinic acid displayed best } \\
\text { docking scores for the inhibition of } \alpha \text {-glucosidase, } \\
\alpha \text {-glucosidase and lipase activities }\end{array}$ \\
\hline
\end{tabular}


Table 3. Overview of studies reporting on the ameliorative effect of tea and fruits-rich in gallic acid against obesity-associated complications.

\begin{tabular}{|c|c|c|c|}
\hline Author, Year & Experimental Model, Dose Used, and Intervention Period & Comparative/Combination Therapy & Experimental Outcome and Proposed Mechanism \\
\hline Ikeda et al., 2005 [15] & $\begin{array}{l}\text { High fat diet fed male Sprague Dawley rats treated with tea } \\
\text { catechins or heat-treated catechins extracts, which are rich in } \\
\text { epigallocatechin gallate and epicatechin gallate at } 1 \% \text { in diet } \\
\text { and fed for } 23 \text { days }\end{array}$ & None & $\begin{array}{l}\text { Tea and the extracts markedly reduced visceral fat } \\
\text { deposition and hepatic triglyceride levels. The activities of } \\
\text { fatty acid synthase and malic enzyme were also decreased }\end{array}$ \\
\hline Amin and Nagy, 2009 [119] & $\begin{array}{l}\text { High fat diet fed male albino rats treated with herbal mixture } \\
\text { extract rich in gallic acid at } 790 \mathrm{mg} / \mathrm{kg} \text { body weight for } 4 \text { weeks }\end{array}$ & $\begin{array}{l}\text { L-carnitine was used at } 250 \mathrm{mg} / \mathrm{kg} \text { body weight } \\
\text { for } 4 \text { weeks }\end{array}$ & $\begin{array}{c}\text { The extract and carnitine improved disturbed lipid profile, } \\
\text { defective antioxidant stability, and high values of insulin } \\
\text { resistance parameters }\end{array}$ \\
\hline Hogan et al., 2010 [120] & $\begin{array}{c}\text { High fat diet fed male C57BLK } / 6 \mathrm{~J} \text { mice treated with Norton } \\
\text { grape pomace extract rich in garlic acid at } 2.4 \mathrm{~g} / \mathrm{kg} \text { of feed in } \\
\text { order to dose each mouse at approximately } 250 \mathrm{mg} \text { GPE } / \mathrm{kg} \\
\text { body weight for } 12 \text { weeks }\end{array}$ & None & $\begin{array}{l}\text { The extract lowered plasma C-reactive protein levels. } \\
\text { However, the extract did not improve oxidative stress as } \\
\text { determined by plasma Oxygen Radical Absorbance } \\
\text { Capacity (ORAC) assay, glutathione peroxidase, and liver } \\
\text { lipid peroxidation }\end{array}$ \\
\hline Cao et al., 2011 [121] & $\begin{array}{l}\text { High fat diet fed male Sprague-Dawley rats treated with Pu-erh } \\
\text { tea extract at } 0.5 \mathrm{~g}, 2 \mathrm{~g} \text { and } 4 \mathrm{~g} / \mathrm{kg} \text { body weight for } 8 \text { weeks }\end{array}$ & None & $\begin{array}{c}\text { The extract significantly lowered plasma total cholesterol, } \\
\text { triglyceride concentrations and low-density } \\
\text { lipoprotein-cholesterol levels. It further enhanced mRNA } \\
\text { levels of hormone-sensitive lipase }\end{array}$ \\
\hline Chang et al., 2011 [102] & $\begin{array}{l}\text { In vitro molecular docking screening of traditional Chinese } \\
\text { medicine, rich in gallic acid, for inhibition of fat mass and } \\
\text { obesity-associated protein activity }\end{array}$ & $\begin{array}{l}\text { (S)-tryptophan-betaxanthin, } \\
\text { 3-methoxytyramine-betaxanthin, } \\
\text { 4-O-methylgallic acid, syringic acid, ethacrynic } \\
\text { acid, ferulic acid, caffeic acid, canavanine, and } \\
\text { 3-methylthymidine }\end{array}$ & $\begin{array}{l}\text { Gallic acid, together with }(S) \text {-tryptophan-betaxanthin, } \\
\text { 3-methoxytyramine-betaxanthin and 4-O-methylgallic acid } \\
\text { were among the leading compounds shown to inhibit fat } \\
\text { mass and obesity-associated protein activity }\end{array}$ \\
\hline Koh et al., 2011 [122] & $\begin{array}{l}\text { High fat diet fed male Sprague Dawley rats treated with } \\
\text { Chinese sweet leaf tea (Rubus suavissimus), rich in gallic acid, at } \\
0.22 \mathrm{~g} / \mathrm{kg} \text { body weight for } 9 \text { weeks }\end{array}$ & None & $\begin{array}{l}\text { Significantly reduced body weight gain and abdominal fat } \\
\text { gain. Although food intake was not affected, blood glucose } \\
\text { was lowered, serum triglycerides and cholesterol were } \\
\text { significantly reduced }\end{array}$ \\
\hline Peng et al., 2011 [123] & $\begin{array}{l}\text { High fat diet fed male Syrian golden hamsters treated with } \\
\text { mulberry water extracts, rich in gallic acid, at } 0.5 \%, 1 \% \text { and } 2 \% \\
\text { of extract supplemented in diet for } 12 \text { weeks }\end{array}$ & None & $\begin{array}{l}\text { The extracts lowered body weight and visceral fat, } \\
\text { accompanied with hypolipidemic effects by reducing } \\
\text { serum triacylglycerol, cholesterol, free fatty acid, and the } \\
\text { low-density lipoprotein/high-density lipoprotein ratio }\end{array}$ \\
\hline \multirow[t]{2}{*}{ Makihara et al., 2012 [98] } & $\begin{array}{c}\text { Type } 2 \text { diabetic obese male TSOD mice treated with a hot water } \\
\text { extract of Terminalia bellirica, rich in gallic acid, at } 1 \% \text { and 3\% } \\
\text { supplemented in diet for } 8 \text { weeks }\end{array}$ & \multirow[t]{2}{*}{ None } & $\begin{array}{l}\text { The extract displayed preventive effect on obesity, insulin } \\
\text { resistance, and hyperlipidemia. It suppressed absorption of } \\
\text { triacylglycerol in an olive oil loading test (in vivo test) }\end{array}$ \\
\hline & In vitro pancreatic lipase activity inhibitory assay & & Demonstrated inhibitory effect on pancreatic lipase activity \\
\hline Yuda et al., 2012 [99] & $\begin{array}{l}\text { In vitro pancreatic lipase inhibitory assay for black tea (Camellia } \\
\text { sinensis) extracts rich in gallic acid }\end{array}$ & $\begin{array}{l}\text { Theaflavin 3-O-gallate, theaflavin 3'-O-gallate, } \\
\text { theaflavin } 3,3^{\prime}-O \text {-gallate, epigallocatechin } \\
\text { gallate, and epicatechin gallate }\end{array}$ & $\begin{array}{l}\text { All extracts inhibited pancreatic lipase but extracts obtained } \\
\text { at } 100 \text { to } 140{ }^{\circ} \mathrm{C} \text { showed the greatest lipase inhibition (IC50s } \\
\text { of } 0.9 \text { to } 1.3 \mu \mathrm{g} / \mathrm{mL} \text { ) }\end{array}$ \\
\hline Esposito et al., 2015 [11] & $\begin{array}{l}\text { High fat diet fed male C57BL/6J mice treated blackcurrant } \\
\text { (Ribes nigrum L), rich in gallic acid, at } 1 \% \text { supplemented diet for } \\
8 \text { weeks }\end{array}$ & None & $\begin{array}{l}\text { The extract reduced body weight gain and improved } \\
\text { glucose metabolism }\end{array}$ \\
\hline
\end{tabular}


Table 3. Cont

\begin{tabular}{|c|c|c|c|}
\hline Author, Year & Experimental Model, Dose Used, and Intervention Period & Comparative/Combination Therapy & Experimental Outcome and Proposed Mechanism \\
\hline Monika and Geetha, 2015 [124] & $\begin{array}{l}\text { High fat diet fed male Sprague Dawley rats treated with } \\
\text { hydro-alcoholic fruit extract of avocado, rich in gallic acid, at } \\
100 \mathrm{mg} / \mathrm{kg} \text { body weight for } 11 \text { weeks }\end{array}$ & None & $\begin{array}{l}\text { The extract reduced body mass index, adiposity index, total } \\
\text { fat pad mass, blood cholesterol, triglycerides, and } \\
\text { low-density lipoprotein. In addition, mRNA expression } \\
\text { levels of fatty acid synthase, lipoprotein lipase, and leptin } \\
\text { in adipose tissue was reduced }\end{array}$ \\
\hline Colantuono et al., 2016 [125] & $\begin{array}{c}\text { In vitro } \alpha \text {-glucosidase, } \alpha \text {-amylase and lipase inhibitory assays } \\
\text { to assess pomegranate peels enriched cookies containing high } \\
\text { levels of gallic acid and its derivatives }\end{array}$ & None & $\begin{array}{l}\text { Showed inhibitory activity against } \alpha \text {-glucosidase, } \\
\alpha \text {-amylase and } \alpha \text {-lipase activities }\end{array}$ \\
\hline De Camargo et al., 2016 [126] & $\begin{array}{c}\text { In vitro antioxidant assays, as well as } \alpha \text {-glucosidase and lipase } \\
\text { inhibitory activities for phenolics from winemaking } \\
\text { by-products rich in gallic acid }\end{array}$ & None & $\begin{array}{l}\text { In addition to strong antioxidant potential, extracts showed } \\
\text { inhibition of } \alpha \text {-glucosidase and lipase activities }\end{array}$ \\
\hline Park et al., 2016 [127] & $\begin{array}{l}\text { High fat diet fed male C57BL } / 6 \text { mice treated with an aqueous } \\
\text { ethanol extraction of black tea, rich in gallic acid, at } 100 \text { and } 300 \\
\text { mg/kg body weight for } 8 \text { weeks. 3T3-L1 adipocytes were } \\
\text { exposed to } 100 \text { and } 300 \mu \mathrm{m} / \mathrm{mL} \text { during differentiation }\end{array}$ & None & $\begin{array}{c}\text { Reduced body weight and body fat, improved fatty liver, } \\
\text { regulated blood glucose, and decreased blood cholesterol. } \\
\text { However, it did not have an effect on PPAR } \gamma \\
\text { protein expression }\end{array}$ \\
\hline $\begin{array}{l}\text { Septembre-Malaterre et al., } \\
2016 \text { [128] }\end{array}$ & $\begin{array}{l}\text { 3T3-L1 pre-adipocytes treated with pineapple and mango } \\
\text { extracts, rich in garlic acid, at } 25 \mu \mathrm{M} \text { for } 1 \mathrm{~h}\end{array}$ & None & $\begin{array}{l}\text { Inhibited hydrogen peroxide induced production of } \\
\text { reactive oxygen species }\end{array}$ \\
\hline Torabi and DiMarco, 2016 [129] & $\begin{array}{l}\text { 3T3-F442A pre-adipocytes treated with grape powder extract, } \\
\text { rich in gallic acid, at } 125-500 \mathrm{mg} \mathrm{GP} / \mathrm{mL} \text { during } \\
\text { differentiation period }\end{array}$ & None & $\begin{array}{c}\text { The extract dose dependently induced adipocyte } \\
\text { differentiation via upregulation of glucose transported } \\
\text { (GLUT) 4, phosphatidylinositol-4,5- bisphosphate 3-kinase } \\
\text { (PI3K) and adipogenic genes }\end{array}$ \\
\hline Pascual-Serrano et al., 2017 [130] & $\begin{array}{l}\text { High fat diet fed male Wistar rats treated with grape seed } \\
\text { proanthocyanidin, rich in gallic acid, at } 25 \mathrm{mg} \text { GSPE } / \mathrm{kg} \text { body } \\
\text { weight for } 3 \text { weeks }\end{array}$ & $\begin{array}{c}\text { Gallic acid was used at } 7 \mathrm{mg} \text { gallic acid } / \mathrm{kg} \text { body } \\
\text { weight for } 3 \text { weeks }\end{array}$ & $\begin{array}{c}\text { Treatments did not reduce weight gain or reverse adiposity } \\
\text { However, the extract induced antihypertrophic and } \\
\text { hyperplasic activities in white adipose tissue through } \\
\text { enhancing perilipin-1 and fatty acid binding protein } 4 \\
\text { expression and restoring adiponectin }\end{array}$ \\
\hline Simao et al., 2017 [131] & $\begin{array}{l}\text { In vitro } \alpha \text {-amylase, } \alpha \text {-glycosidase, lipase, and trypsin enzymes } \\
\text { assays on aqueous extract from three cultivars of Psidium } \\
\text { guajava L. (Pedro Sato, Paluma and Século XXI) rich in } \\
\text { gallic acid }\end{array}$ & None & $\begin{array}{l}\text { In presence of simulated gastric fluid, all cultivars showed } \\
\text { increase in the inhibition of lipase and } \alpha \text {-glycosidase, and } \\
\text { decrease in inhibition of } \alpha \text {-amylase and trypsin enzymes }\end{array}$ \\
\hline Ge et al., 2018 [132] & $\begin{array}{c}\text { The network-based pharmacological analysis was used to } \\
\text { assess mulberry leaves rich in gallic acid }\end{array}$ & None & $\begin{array}{c}\text { The extract regulated Tnf- } \alpha, \text { PPAR } \gamma \text {, glycogen synthase } \\
\text { kinase- } 3 \text { beta (GSK3B), insulin receptor substrate } 1 \text { (IRS1), } \\
\text { interleukin } 6 \text { (IL-6) and other proteins involved in diabetes } \\
\text { and obesity associated complications }\end{array}$ \\
\hline $\begin{array}{l}\text { Sandoval-Gallegos et al., } \\
\quad 2018[133]\end{array}$ & $\begin{array}{l}\text { High fat diet fed male Wistar rats treated with methanolic acid } \\
\text { extract of Mangifera indica L. leaves, rich in gallic acid, at 100, } \\
\qquad 200 \text { and } 400 \mathrm{mg} / \mathrm{kg} \text { for } 32 \text { days }\end{array}$ & None & $\begin{array}{l}\text { In addition to increasing antioxidant capacity, the extract } \\
\text { improved hyperlipidemic markers such as cholesterol, } \\
\text { triglycerides, and atherogenic index }\end{array}$ \\
\hline Wu and Tian, 2018 [134] & $\begin{array}{l}\text { In vitro } \alpha \text {-glucosidase, } \alpha \text {-amylase and lipase inhibitory activity } \\
\text { of flowers of pomegranate (Punica granatum) rich in gallic acid }\end{array}$ & Acarbose & $\begin{array}{l}\text { The extract showed enhanced effect of suppress } \\
\alpha \text {-glucosidase, } \alpha \text {-amylase, and lipase activities }\end{array}$ \\
\hline
\end{tabular}


Table 4. Overview of studies reporting on the ameliorative effects of other gallic acid-rich plants against obesity-associated complications.

\begin{tabular}{|c|c|c|c|}
\hline Author, Year & Experimental Model, Dose Used, and Intervention Period & Comparative/Combination Therapy & Experimental Outcome and Proposed Mechanism \\
\hline Wu et al., 2010 [135] & $\begin{array}{l}\text { High fat diet fed male C57BL } / 6 \text { mice treated with Nelumbo } \\
\text { nucifera leaf extract-rich in gallic acid, supplemented at } 0.5 \% \text { in } \\
\text { diet for } 6 \text { weeks }\end{array}$ & $\begin{array}{c}\text { Simvastatin was used at } 1 \mathrm{mg} / \mathrm{kg} \text { body weight, } \\
\text { while silymarin was used at } 100 \mathrm{mg} / \mathrm{kg} \text { body } \\
\text { weight for } 6 \text { weeks }\end{array}$ & $\begin{array}{c}\text { The extract performed comparable to simvastatin and } \\
\text { silymarin in reducing body weight, body lipid } \\
\text { accumulation, and activities of fatty acid synthase, glutamic } \\
\text { oxaloacetic transaminase, and glutamic } \\
\text { pyruvic transaminase }\end{array}$ \\
\hline Batista et al., 2014 [136] & $\begin{array}{l}\text { High fat diet fed male Sprague Dawley rats treated } \\
\text { freeze-dried jaboticaba peel extract, rich in gallic acid, at } 1 \% \text {, } \\
2 \% \text { and } 4 \% \text { supplemented diet for } 6 \text { weeks }\end{array}$ & None & $\begin{array}{l}\text { In addition to reducing circulating saturated free fatty acids, } \\
\text { the extract prevented lipid peroxidation in the liver and } \\
\text { increased its antioxidant defenses }\end{array}$ \\
\hline Foddai et al., 2014 [137] & $\begin{array}{l}\text { In vitro pancreatic triacylglycerol lipase, } \alpha \text {-amylase and } \\
\alpha \text {-glucosidase inhibitory assays for Limonium spp } \\
\text { (Plumbaginaceae) rich in epigallocatechins }\end{array}$ & $\begin{array}{l}\text { Compared with acarbose, aqueous extracts of } L \text {. } \\
\text { contortirameum and L. virgatum }\end{array}$ & $\begin{array}{l}\text { All extract showed inhibitory activity on pancreatic } \\
\text { triacylglycerol lipase, } \alpha \text {-amylase and } \alpha \text {-glucosidase }\end{array}$ \\
\hline Irondi et al., 2016 [138] & $\begin{array}{l}\text { In vitro pancreatic lipase and angiotensin 1-converting enzyme } \\
\text { inhibitory assays for Ocimum basilicum extracts containing } \\
\text { gallic acid }\end{array}$ & Ocimum gratissimum extracts & $\begin{array}{l}\text { All extracts displayed high antioxidant properties. } \\
\text { However, Ocimum basilicum displayed slightly lower } \\
\text { activity than Ocimum gratissimum to inhibit pancreatic } \\
\text { lipase and angiotensin 1-converting enzyme }\end{array}$ \\
\hline Abeysekera et al., 2017 [139] & $\begin{array}{l}\text { In vitro antilipidemic assays assessing potential of bark } \\
\text { extracts of Ceylon Cinnamon rich in gallic acid }\end{array}$ & None & $\begin{array}{c}\text { The extract showed inhibitory effect against HMG-CoA } \\
\text { reductase, lipase, cholesterol esterase, and } \\
\text { cholesterol micellization }\end{array}$ \\
\hline Donado-Pestana et al., 2018 [19] & $\begin{array}{l}\text { High fat diet fed male C57BL } / 6 \mathrm{~J} \text { mice treated with cagaita } \\
\text { (Eugenia dysenterica } \mathrm{DC} \text {.) extracts at } 7 \text { and } 14 \mathrm{mg} \text { gallic acid } \\
\text { equivalent (GAE) } / \mathrm{kg} \text { body weight for } 8 \text { weeks }\end{array}$ & None & $\begin{array}{l}\text { The extract protected against dyslipidemia, fasting } \\
\text { hyperglycemia, and attenuated both hepatic } \\
\text { gluconeogenesis and inflammation as observed by the } \\
\text { expression of tumor necrosis factor alpha (TNF- } \alpha \text { ) and } \\
\text { transcriptional factor NF-KB }\end{array}$ \\
\hline
\end{tabular}




\section{Evidence on the Anti-Obesity Properties of Gallic Acid}

Although gallic acid was shown to be active against complications such as hemoptysis as early as the 1800s [140], studies reporting on its anti-obesity properties started emerging about three decades ago [113]. A search with the terms "gallic acid and metabolic disease" resulted in approximately 246 articles; however, only 60 studies were specific to gallic acid and its ameliorative effects against obesity associated complications. Data reporting on the ameliorative effect of gallic acid or its derivative compounds, as well as tea, fruits and other plants containing this phenolic acid are summarized in Tables 1-4, while information on the effect of gallic acid in human studies is presented in Table 5 . Information presented in each table includes author details, year of publication, experimental model and dose used, as well as the proposed mechanism of action, if any was investigated.

Through the use of experimental models discussed above, gallic acid has demonstrated an increased potential to ameliorate a number obesity associated complications, as summarized in Table 1. Concise evidence shows that gallic acid presents with and enhanced effect to reduce body weights in obese rodents $[95,105,107]$. This effect can either be directly via inhibiting formation of lipid droplets in the liver or adipose tissue, as well as directly by reducing serum levels of triglycerides and low-density lipoprotein $[105,106]$. In cultured adipocytes or HFD fed rats, such properties have been confirmed $[17,18,103]$, with the modulation of glucose and lipid metabolism implicated as the major mechanism proposed to be involved in the therapeutic benefits of gallic acid. Indeed, the modulatory effect of lipids and glucose intermediates could be related to its effects in improving glucose uptake [109,112], increasing energy expenditure [110], and enhancing insulin sensitivity [20,109]. Albeit regulation of PI3K/Akt signaling could explain its therapeutic potential in enhancing insulin sensitivity $[20,112]$, activation of AMP-activated protein kinase (AMPK) by gallic acid might influence substrate metabolism, as reported elsewhere [111]. Nonetheless, several other natural compounds such as celastrol and resveratrol have been shown to control glucose and lipid metabolism and thereby ameliorate obesity associated complications, including inflammation and oxidative stress through mostly modulating mechanisms such PI3K/Akt and AMPK [147,148]. In any case, although limited information is available on its effect on inflammation, studies summarized in this review support strong ameliorative effects of gallic acid against oxidative stress $[104,105,108]$. From these studies, enhancing intracellular antioxidants such as glutathione and blocking lipid peroxidation products is linked with reduced oxidative stress. 
Table 5. Human studies reporting on the therapeutic potential of gallic acid or gallic acid rich plants against obesity-associated complications.

\begin{tabular}{|c|c|c|c|}
\hline Author, Year. & Experimental Model, Dose Used, And Intervention Period & Comparative/Combination Therapy & Experimental Outcome and Proposed Mechanism \\
\hline Roberts, 2006 [141] & $\begin{array}{l}\text { Obese human subjects receiving capsules containing } 200 \mathrm{mg} \text { of } \\
\text { gallic acid and } 50 \mathrm{mg} \text { of a Chinese herbal decoction, three times } \\
\text { a day for } 24 \text { weeks }\end{array}$ & None & $\begin{array}{l}\text { Did not cause weight loss or a decrease in food intake in } \\
\text { humans, principally due to the inability to achieve } \\
\text { adequate serum levels }\end{array}$ \\
\hline Greenway et al., 2006 [142] & $\begin{array}{l}\text { Overweight women receiving number ten supplement ( } 6 \text { and } \\
\text { mg/day), containing gallic acid, for } 8 \text { weeks }\end{array}$ & None & $\begin{array}{c}\text { The supplement did not affect weight change; however hac } \\
\text { varied effect in food intake }\end{array}$ \\
\hline Heber et al., 2007 [143] & $\begin{array}{l}\text { Overweight human subjects received one or two pomegranate } \\
\text { ellagitannin-enriched polyphenol extract capsules per day } \\
\text { providing } 710 \mathrm{mg}(435 \mathrm{mg} \text { of gallic acid equivalents, GAEs) or } \\
1420 \mathrm{mg}(870 \mathrm{mg} \text { of GAEs) of extracts, respectively }\end{array}$ & None & $\begin{array}{l}\text { Improved antioxidant activity through a significant } \\
\text { reduction in thiobarbituric acid reactive substances }\end{array}$ \\
\hline $\begin{array}{l}\text { Skrzypczak-Jankun and Jankun, } \\
2010[144]\end{array}$ & $\begin{array}{l}\text { Plasma from human subjects treated with theaflavin digallate } \\
\text { at } 18 \mu \mathrm{M} \text { for } 30 \mathrm{~min}\end{array}$ & $\begin{array}{c}\text { PAI-1 inhibitor PAI039 and } \\
\text { epigallocatechin-3-gallate were used at } 15 \mu \mathrm{M} \\
\text { for } 30 \mathrm{~min}\end{array}$ & $\begin{array}{l}\text { Inactivated plasminogen activator inhibitor type } \\
\text { one (PAI-1) }\end{array}$ \\
\hline Kubota et al., 2011 [145] & $\begin{array}{l}\text { Pre-obese Japanese human subjects treated with water-soluble } \\
\text { black Chinese (Pu-Erh) tea extract rich in gallic acid at } 333 \mathrm{mg} \\
\text { for } 12 \text { weeks }\end{array}$ & None & $\begin{array}{l}\text { Exhibited significant effects in reducing the mean waist } \\
\text { circumference, body mass index, and visceral fat values }\end{array}$ \\
\hline Hernández et al., 2015 [146] & $\begin{array}{l}\text { Obese patients undergoing biliopancreatic diversion received } \\
\text { treatment with } 2 \text { courses of oral bismuth subgallate at } 200 \mathrm{mg} \\
\text { every } 8 \mathrm{~h} \text { for } 12 \text { weeks, with a } 4 \text {-week rest period }\end{array}$ & None & Improved the quality of life score of patients \\
\hline
\end{tabular}


Furthermore, it appears that increasing adiponectin levels and regulating genes involved in adipogenesis and proliferation may be another mechanism by which gallic acid attenuates obesity associated complications [16,21]. For instance, through upregulation of peroxisome proliferator-activated receptor (PPAR) $\gamma$ expression and activation of NAD-dependent deacetylase sirtuin-1 (SIRT1)/peroxisome proliferator activated receptor gamma coactivator 1 alpha (PGC1 $\alpha)$ pathway this phenolic acid can induce browning of the adipose tissue [111]. It can influence adipogenesis by upregulating protein expression of fatty acid synthase (FAS), FAS ligand (FasL), as well as tumor protein 53 (p53) and activated caspase $3 / 9$ [21]. Interestingly, similar to the mechanism attributed to statin drugs, gallic acid can interfere with cholesterol synthesis by blocking the activity of $\beta$-Hydroxy $\beta$-methylglutaryl-CoA (HMG-CoA) reductase [108]. However, although data on its comparison with a known antidiabetic agent, pioglitazone [20], there is very limited literature that compares the beneficial effects of gallic acid with widely used anti-obesity or antidiabetic drugs.

\section{Evidence on the Anti-Obesity Effects of Gallic Acid Derived Compounds}

Table 2 summarizes some of the well-investigated derivatives of gallic acid for their anti-obesity properties, including 6-deoxytetra-O-galloyl- $\alpha$-D-glucopyranose, tetra-O-galloyl- $\alpha$-D-xylopyranose, 6-chloro-6-deoxy-1,2,3,4-tetra-O-galloyl- $\alpha$-D-glucopyranose, epigallocatechin gallate, epicatechin-3gallate, N-(4-(tert-Butyl)phenyl)-3,4,5-trihydroxybenzamide (KMU-3), and methyl gallate $[14,17,101,114-$ $118,144,146]$. Briefly, some evidence summarized in Table 2 demonstrates that the therapeutic effects of gallic acid were less effective when compared to a few pharmacological compounds, including some of its derivatives. For example, tannic acid displayed better effect in attenuating insulin-stimulated lipogenesis through activation of insulin-receptor-associated tyrosine kinase phosphorylation in Wistar rats [113]. $\mathrm{O}$-coumaric acid and rutin displayed a better effect on inhibiting glycerol-3-phosphate dehydrogenase activity, and reducing the expression of PPAR $\gamma$, CCAAT/enhancer-binding proteins (C/EBP) and leptin in cultured 3T3-L1 adipocytes [96]. Epigallocatechin gallate performed better in decreasing insulin stimulated glucose uptake, with the mechanistic involvement of AMPK pathway [97]. Moreover, (z)-3-(3,4,5-trihydroxybenzoyloxy) propane-1,2-diyl dioleate showed a more pronounced effect than gallic acid in reducing the body weight in Wistar rats [22]. KMU-3 outperformed gallic acid in suppressing lipid accumulation in 3T3-L1 adipocytes by downregulating the expressions of C/EBP- $\alpha$, PPAR $\gamma$, and FAS [116]. Although did not show superior effect when compared to gallic acid, the other derivative compounds of this phenolic acid such as 6-deoxytetra-O-galloyl- $\alpha$-D-glucopyranose, tetra-O-galloyl- $\alpha$-D-xylopyranose, epigallocatechin-3-gallate, epigallocatechin 3-O-(3-O-methyl) gallate and methyl gallate have presented and enhanced effect at improving glucose uptake, inhibiting pancreatic lipase activity, and blocking adipogenesis and proliferation, respectively $[14,101,114,115$, 117,118]. The proposed mechanisms associated with the aforementioned beneficial effects include regulation of CCAAT/enhancer-binding proteins (C/EBPR) and PPAR $\gamma$ expression, as well as stimulation of $\mathrm{Wnt} / \beta$-catenin signaling to mostly block adipogenesis and proliferation.

\section{Evidence on the Anti-Obesity Properties of Tea and Fruits Containing Gallic Acid}

Table 3 summarizes primary studies reporting on the beneficial effects of tea and fruits containing gallic acid or its derivative compounds against obesity associated complications. Besides tea (Camellia sinensis), fruits that have been shown to contain high levels of gallic acid or its derivative compounds include avocado, ellagitannin-enriched polyphenolic extract, Eugenia dysenterica DC., freeze-dried jaboticaba peel, grape powder, herbal mixture, Limonium spp. (Plumbaginaceae), Mangifera indica L., mango, mulberry water, Nelumbo nucifera leaf, Norton grape pomace, number ten supplement, Ocimum basilicum, pineapple, pomegranate peels, Psidium guajava L., Pedro Sato, Paluma and Século XXI, Pu-erh tea, Punica granatum, Ribes nigrum L, Rubus suavissimus, and Terminalia bellirica $[11,15,19,98$, 99,102,119-139,142,143,145].

From data presented in Table 3, tea appears to be the leading gallic acid-rich product that is explored for its anti-obesity properties. This may be due to the fact that tea is among the world's most 
consumed beverage and is increasingly targeted for the treatment of lifestyle diseases [149]. Tea exists in various forms, with green tea prepared in an unoxidized form, oolong partially oxidized, Pu-erh teas requiring boiling water for infusion, while black tea undergoing the complete oxidation process [150]. Although present at varying amounts, all teas contain relatively high levels of catechins and gallic acid [150,151]. Previous reports show that green tea can suppress adipogenesis and lipid synthesis by increasing energy expenditure via thermogenesis, fat oxidation and fecal lipid excretion [152]. Consistently, evidence on this review showed that black and Pu-erh teas have great potential in ameliorating obesity associated complications by mainly reducing visceral fat deposition and lowering hepatic triglyceride levels [15,117,121,122,127,145].

Lowering plasma total cholesterol, triglyceride concentrations and low-density lipoproteincholesterol levels, in addition to reducing activities of FAS and malic enzyme, are proposed to be the mechanisms involved in the beneficial effects of tea against obesity linked complications. Thus, suggesting that additional studies are required to explore molecular mechanisms involved in the beneficial effect of gallic acid-rich teas against obesity associated complications, especially targeting its role in adipogenesis, insulin signaling, inflammation, and oxidative stress processes.

In addition to tea, evidence on the therapeutic potential of fruits rich in gallic acid or its derivatives in preventing obesity has also emerged. Fruits of interest include avocado, blackcurrant, grapes, guava, mango, mulberry, and pomegranate (Figure 4). Most of these fruits are commercially available, and their regular consumption has been linked with various health benefits. For instance, avocado (Persea americana) extract at $100 \mathrm{mg} / \mathrm{kg}$ body weight was found to significantly reduce body mass index, adiposity index, total fat pad mass, blood cholesterol, triglycerides, and low-density lipoprotein in HFD fed rats [124]. Blackcurrant (Ribes nigrum) supplemented in diet for eight weeks reduced body weight gain and improved glucose metabolism in HFD fed mice [11]. Although limitations in decreasing oxidative stress in obese female mice have been observed [120], several beneficial effects for grapes (Vitis vinifera) extracts have been identified by other researchers in cultured adipocytes and obese rodents $[120,129,130]$. The beneficial effects include the capacity of this grape extract to reduce plasma C-reactive protein levels, improve glucose uptake and insulin signaling, which may be related to enhanced expression of perilipin-1, fatty acid binding protein 4, GLUT4, as well as PI3K. Another gallic acid-rich fruit, guava (Psidium guajava L.), using in vitro-based assays, demonstrated inhibitory effects on lipase, $\alpha$-glycosidase, $\alpha$-amylase and trypsin enzyme activities in the presence of simulated gastric fluid [131]. Whereas in cultured adipocytes, mango (Mangifera indica) extract showed inhibitory effect against hydrogen peroxide induced production of ROS [128]. On the other hand, mulberry (Morus alba L.) extracts supplemented in diet were shown to reduce body weight of obese mice by suppressing visceral fat, accompanied with hypolipidemic effects through the reduction in serum triacylglycerol, cholesterol, and the low-density lipoprotein/high-density lipoprotein ratio [123]. Similarly, using a network-based pharmacological analysis, mulberry extracts have been proposed to regulate TNF- $\alpha$, PPAR $\gamma$, glycogen synthase kinase-3 beta (GSK3B), insulin receptor substrate 1 (IRS1), interleukin 6 (IL-6) and other proteins involved in diabetes and obesity associated complications [132]. Last but not least, pomegranate (Punica granatum) extracts, using in vitro screening tools have demonstrated an enhanced effect to suppress $\alpha$-glucosidase, $\alpha$-amylase, and lipase activities [134]. Overall results presented in this review support the beneficial effects of fruits-rich in gallic acid on ameliorating obesity associated complications [11,120,123,124,128-134]. However, most of these studies fall short in confirming in vitro findings on other in vivo models, while also demonstrating limitation in unravelling molecular mechanisms by which these fruits can protect against obesity linked anomalies. 


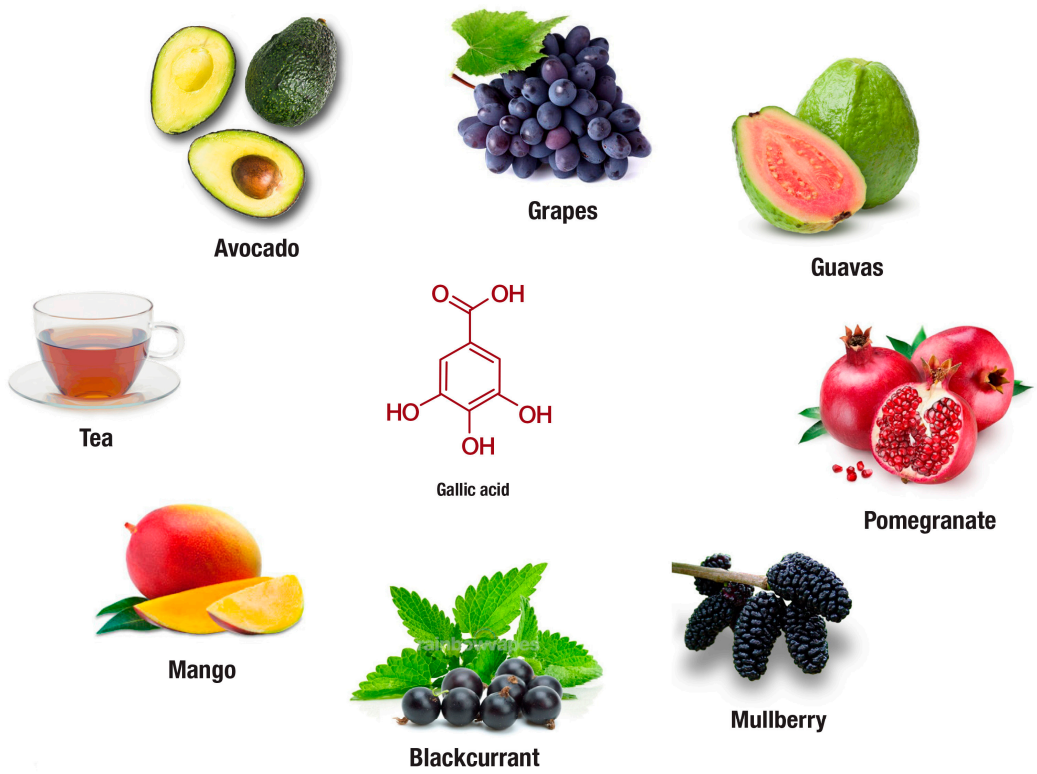

Figure 4. In addition to tea, avocado, blackcurrant, grapes, guava, mango, mulberry and pomegranate are some plants rich in gallic acid or its derivative compounds that are increasingly investigated for their anti-obesity properties. The following websites were used for the extraction of images: Tea, https:/ / www.coffeebean.com/cafe-menu/tea; Avocado, https://draxe.com/avocado-benefits/; Grapes, https:/ / www.indiamart.com/proddetail/purple-grapes-16445565830.html; Guava, https:/ / exoticflora.in/products / guava-red-flesh-fruit-plants-tree; Mango, http:/ / www.adagio.com/flavors / mango.html; Blackcurrant, https: / / tmbnotes.co/BlackcurrantMentholConcentrate; Mulberry, https: / / www.amazon.com/Dwarf-Everbearing-Mulberry-Plant-Morus/dp/B008BB8VOW; Pomegranate, https:/ / www.organicfacts.net/health-benefits/fruit/health-benefits-of-pomegranate.html.

\section{Anti-Obesity Properties of other Plants Rich in Gallic Acid}

Besides wine-making products, other plant extracts and products rich in gallic acid or its derivatives include cagaita (Eugenia dysenterica), Ceylon cinnamon (Cinnamomum verum), jaboticaba (Plinia cauliflora), Limonium, Nelumbo nucifera, Ocimum basilicum and Terminalia bellirica (Table 4). Through the use of various experimental models these plant extracts display a broad spectrum of ameliorative effects against obesity associated complications. For example, the use of herbal mixture extract rich in gallic acid at $790 \mathrm{mg} / \mathrm{kg}$ body weight for 4 weeks improved lipid profile, defective antioxidant stability, and insulin resistance in HFD fed rats [119]. In a similar model of obesity, the use of cagaita extracts at 7 and $14 \mathrm{mg}$ gallic acid equivalent for 8 weeks protected against dyslipidemia, fasting hyperglycemia, and further attenuated both hepatic gluconeogenesis and inflammation as observed by the expression of TNF- $\alpha$ and transcriptional factor NF- $\mathrm{KB}$ [19]. Based on in vitro assays, the bark extracts of Ceylon Cinnamon showed increased potential to inhibit HMG-CoA reductase, lipase and cholesterol esterase [139]. On the other hand, supplementation with Jaboticaba peel extract for 6 weeks reduced circulating saturated FFAs, blocked lipid peroxidation in the liver and increased its antioxidant defenses in obese rats [136]. Administration of Nelumbo nucifera leaf extract mixed at $0.5 \%$ in diet for 6 weeks was able to reduce body weight, body lipid accumulation, and the enzymatic activity of FAS, glutamic oxaloacetic transaminase, and glutamic pyruvic transaminase in obese mice [135]. Limonium spp. (Plumbaginaceae), a epigallocatechin-rich extract inhibited the activities of pancreatic triacylglycerol lipase, $\alpha$-amylase and $\alpha$-glucosidase [137]. Moreover, Ocimum basilicum and Terminalia bellirica extracts were shown to present with high potential to inhibit the activity of $\alpha$-glucosidase, $\alpha$-amylase, lipase, HMG-CoA reductase and angiotensin 1-converting enzyme [98,126,137-139]. Inhibition for some of these enzymes, especially lipase may translate to restricted to food absorption resulting in loss of body weight; however in vivo confirmation of such findings is necessary. Anyway, although there is still some difficulty in achieving reduction in body weights in obese rodent models with gallic acid treatment, the overall findings 
demonstrate that the presence of gallic acid in some plants may enhance their therapeutic effects in preventing obesity associated complications.

\section{Human Studies Reporting on the Therapeutic Potential of Gallic Acid against Obesity-Associated Complications}

Despite the recorded increase in natural product and natural product derived drugs in clinical trials [153], challenges of conducting clinical research of natural products still persists [154]. Toxicity, adverse effects if used on long-term or at the incorrect dosages, and drug-to drug interactions are some of the acknowledged draw backs identified in clinical evaluation of herbal medicine for the treatment of obesity [155-157]. Two of the six clinical studies on the anti-obesity properties of gallic acid included in the current review showed that this phenolic acid or its derivatives did not cause weight loss or affect any of the markers assessed except for reducing food intake in obese subjects assessed [141,142]. However, it is of note that although strong evidence linking consumption of natural supplements with effective management of obesity is insufficient, most natural compounds have been specifically credited for attenuating metabolic complications including systemic inflammation and oxidative stress in overweight and obese individuals [158-160]. The other four included clinical studies supported the beneficial effect of gallic acid and its derivatives in ameliorating some obesity associated complications $[143,144]$. These studies showed that in addition to improving the quality of life score of obese patients undergoing biliopancreatic diversion [146], gallic acid-rich extracts can reduce the mean waist circumference, body mass index, and visceral fat values in pre-obese Japanese human subjects [145], and suppress inflammation and oxidative stress associated markers [143,144]. From clinical results summarized in this review (Table 5), it is clear that future work exploring different doses and larger cohorts is required to fully elucidate the therapeutic potential of gallic acid to combat obesity and associated complications in human subjects. Furthermore, a comparison of its effects with other available treatments, such as lipid lowering drugs and other obesity therapies, is still necessary.

\section{Concluding Remarks}

Obesity and the metabolic syndrome are of significant scientific and clinical interest, due to their contribution in the rapid rise of noncommunicable diseases. Although mechanisms describing the pathophysiology of these complications remain complex, inflammation and oxidative stress are understood to be some of the major causal factors implicated in worsening of obesity associated perturbations. Thus, in addition to reducing raised blood glucose or lipid levels, amelioration of inflammation and oxidative stress may be another basic measure taken to improve cellular function in an obese state. At present, only a few therapies are available to improve the lives of obese patients at high risk of developing the metabolic syndrome. To date, some natural products, including gallic acid have been shown to ameliorate complications associated with the metabolic syndrome. This may be through mechanisms involving the reduction of excessive body fat, or ameliorating inflammation and oxidative stress at a cellular level. Certainly, the pre-clinical data summarized in this review support the beneficial effects of gallic acid or its derivatives in preventing obesity-associated complications. Although demonstrated to partially interfere with allergic disorders by acting on $\mathrm{G}$ protein-coupled receptor-35 [161], it is still not clear which receptors are targeted by gallic acid or how it could modulate the discussed metabolic benefits. Other interesting questions raised in this review include identification of gallic acid metabolites that may be involved in cellular functions, and investigating its broad effect in increasing angiogenesis or endothelial cell function and thereby reduce oxidative stress. The major shortfalls highlighted in this review include limited to no studies assessing the ameliorative effects of gallic acid against obesity-associated complications in human subjects to confirm its therapeutic potential. This can be further complemented with experiments exploring its concurrent use with current lipid-lowering therapies to investigate whether it would of therapeutic benefit as an adjunct therapy. 
Author Contributions: P.V.D., B.B.N., B.J. and S.E.M. conceptualized, designed and drafted the study. All authors including P.V.D., B.B.N., B.J., Z.M., T.M., S.S., P.O., L.T., J.L. and S.E.M. wrote, revised and approved the final version of the review.

Funding: This work was supported by the Biomedical Research and Innovation Platform of the South African Medical Research Council (SAMRC) baseline funding. PV Dludla was partially supported as a Post-Doctoral Fellow by funding from the SAMRC. The grant holder acknowledges that opinions, findings, and conclusions or recommendations expressed in any publication generated by the SAMRC supported research are those of the authors, and that the SAMRC accepts no liability whatsoever in this regard.

Acknowledgments: We would like to thank Paul du Toit of TBND Design Studio for preparing figures for this review.

Conflicts of Interest: The authors declare no conflict of interest. The funders had no role in the design of the study; in the writing of the manuscript, or in the decision to publish the results.

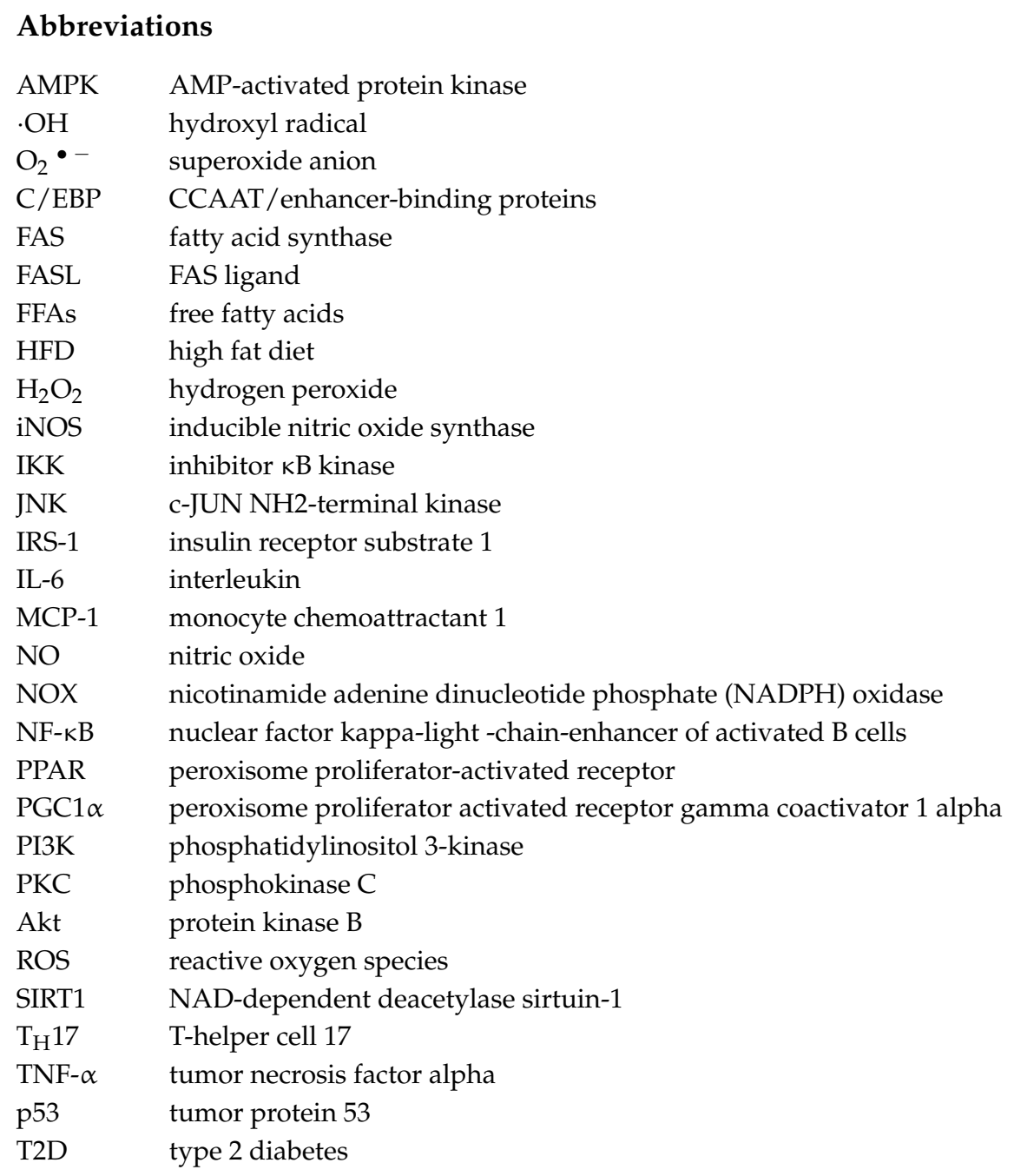

\section{References}

1. World Health Organization. Obesity. Available online: http://www.who.int/en/news-room/fact-sheets/ detail/obesity-and-overweight (accessed on 9 August 2018).

2. Williams, C.B.; Mackenzie, K.C.; Gahagan, S. The effect of maternal obesity on the offspring. Clin. Obstet. Gynecol. 2014, 57, 508-515. [CrossRef] [PubMed]

3. Jung, U.J.; Choi, M.S. Obesity and its metabolic complications: The role of adipokines and the relationship between obesity, inflammation, insulin resistance, dyslipidemia and nonalcoholic fatty liver disease. Int. J. Mol. Sci. 2014, 15, 6184-6223. [CrossRef] [PubMed] 
4. Francisqueti, F.V.; Chiaverini, L.C.; Santos, K.C.; Minatel, I.O.; Ronchi, C.B.; Ferron, A.J.; Ferreira, A.L.; Corrêa, C.R. The role of oxidative stress on the pathophysiology of metabolic syndrome. Rev. Assoc. Med. Bras. 2017, 63, 85-91. [CrossRef] [PubMed]

5. Lumeng, C.N.; Saltiel, A.R. Inflammatory links between obesity and metabolic disease. J. Clin. Investig. 2011, 121, 2111-2117. [CrossRef]

6. Jo, J.; Gavrilova, O.; Pack, S.; Jou, W.; Mullen, S.; Sumner, A.E.; Cushman, S.W.; Periwal, V. Hypertrophy and/or hyperplasia: Dynamics of adipose tissue growth. PLoS Comput. Biol. 2009, 5, e1000324. [CrossRef] [PubMed]

7. Ussar, S.; Lee, K.Y.; Dankel, S.N.; Boucher, J.; Haering, M.F.; Kleinridders, A.; Thomou, T.; Xue, R.; Macotela, Y.; Cypess, A.M.; et al. ASC-1, PAT2, and P2RX5 are cell surface markers for white, beige, and brown adipocytes. Sci. Transl. Med. 2014, 6, 247ra103. [CrossRef] [PubMed]

8. Fernandez-Sanchez, A.; Madrigal-Santillán, E.; Bautista, M.; Esquivel-Soto, J.; Morales-González, A.; Esquivel-Chirino, C.; Durante-Montiel, I.; Sánchez-Rivera, G.; Valadez-Vega, C.; Morales-González, J.A. Inflammation, oxidative stress, and obesity. Int. J. Mol. Sci. 2011, 12, 3117-3132. [CrossRef]

9. Petrovska, B.B. Historical review of medicinal plants' usage. Pharmacogn. Rev. 2012, 6, 1-5. [CrossRef]

10. Lin, D.; Xiao, M.; Zhao, J.; Li, Z.; Xing, B.; Li, X.; Kong, M.; Li, L.; Zhang, Q.; Liu, Y.; et al. An overview of plant phenolic compounds and their importance in human nutrition and management of type 2 diabetes. Molecules 2016, 21, 10. [CrossRef]

11. Esposito, D.; Damsud, T.; Wilson, M.; Grace, M.H.; Strauch, R.; Li, X.; Lila, M.A.; Komarnytsky, S. Black currant anthocyanins attenuate weight gain and improve glucose metabolism in diet-induced obese mice with intact, but not disrupted, gut microbiome. J. Agric. Food Chem. 2015, 63, 6172-6180. [CrossRef]

12. Saibabu, V.; Fatima, Z.; Khan, L.A.; Hameed, S. Therapeutic potential of dietary phenolic acids. Adv. Pharmacol. Sci. 2015, 2015, 823539. [CrossRef]

13. Wang, S.S.; Wang, D.M.; Pu, W.J.; Li, D.W. Phytochemical profiles, antioxidant and antimicrobial activities of three Potentilla species. BMC Complement. Altern. Med. 2013, 13, 321. [CrossRef] [PubMed]

14. Ediriweera, M.K.; Tennekoon, K.H.; Samarakoon, S.R.; Thabrew, I.; de Silva, E.D. Protective effects of six selected dietary compounds against leptin-induced proliferation of oestrogen receptor positive (MCF-7) breast cancer cells. Medicines 2017, 4, 56. [CrossRef]

15. Ikeda, I.; Hamamoto, R.; Uzu, K.; Imaizumi, K.; Nagao, K.; Yanagita, T.; Suzuki, Y.; Kobayashi, M.; Kakuda, T. Dietary gallate esters of tea catechins reduce deposition of visceral fat, hepatic triacylglycerol, and activities of hepatic enzymes related to fatty acid synthesis in rats. Biosci. Biotechnol. Biochem. 2005, 69, 1049-1053. [CrossRef] [PubMed]

16. Makihara, H.; Koike, Y.; Ohta, M.; Horiguchi-Babamoto, E.; Tsubata, M.; Kinoshita, K.; Akase, T.; Goshima, Y.; Aburada, M.; Shimada, T. Gallic acid, the active ingredient of Terminalia bellirica, enhances adipocyte differentiation and adiponectin secretion. Biol. Pharm. Bull. 2016, 39, 1137-1143. [CrossRef]

17. Pandey, A.; Bani, S.; Sangwan, P.L. Anti-obesity potential of gallic acid from Labisia pumila, through augmentation of adipokines in high fat diet induced obesity in C57BL/ 6 mice. Adv. Res. 2014, 2, 556-570. [CrossRef]

18. Chao, J.; Huo, T.I.; Cheng, H.Y.; Tsai, J.C.; Liao, J.W.; Lee, M.S.; Qin, X.M.; Hsieh, M.T.; Pao, L.H.; Peng, W.H. Gallic acid ameliorated impaired glucose and lipid homeostasis in high fat diet-induced NAFLD mice. PLoS ONE 2014, 9, e96969. [CrossRef]

19. Donado-Pestana, C.M.; Dos Santos-Donado, P.R.; Daza, L.D.; Belchior, T.; Festuccia, W.T.; Genovese, M.I. Cagaita fruit (Eugenia dysenterica DC.) and obesity: Role of polyphenols on already established obesity. Food Res. Int. 2018, 103, 40-47. [CrossRef]

20. Gandhi, G.R.; Jothi, G.; Antony, P.J.; Balakrishna, K.; Paulraj, M.G.; Ignacimuthu, S.; Stalin, A.; Al-Dhabi, N.A. Gallic acid attenuates high-fat diet fed-streptozotocin-induced insulin resistance via partial agonism of PPARgamma in experimental type 2 diabetic rats and enhances glucose uptake through translocation and activation of GLUT4 in PI3K/p-Akt signaling pathway. Eur. J. Pharmacol. 2014, 745, 201-216. [CrossRef]

21. Hsu, C.L.; Lo, W.H.; Yen, G.C. Gallic acid induces apoptosis in 3T3-L1 pre-adipocytes via a fas- and mitochondrial-mediated pathway. J. Agric. Food Chem. 2007, 55, 7359-7365. [CrossRef]

22. Totani, N.; Tateishi, S.; Takimoto, T.; Maeda, Y.; Sasaki, H. Gallic acid glycerol ester promotes weight-loss in rats. J. Oleo. Sci. 2011, 60, 457-462. [CrossRef] [PubMed] 
23. Locatelli, C.; Filippin-Monteiro, F.B.; Creczynski-Pasa, T.B. Alkyl esters of gallic acid as anticancer agents: A review. Eur. J. Med. Chem. 2013, 60, 233-239. [CrossRef] [PubMed]

24. Badhani, B.; Sharma, N.; Kakkar, R. Gallic acid: A versatile antioxidant with promising therapeutic and industrial applications. RSC Adv. 2015, 5, 27540-27557. [CrossRef]

25. Choubey, S.; Varughese, L.R.; Kumar, V.; Beniwal, V. Medicinal importance of gallic acid and its ester derivatives: A patent review. Pharm. Pat. Anal. 2015, 4, 305-315. [CrossRef] [PubMed]

26. Fernandes, F.H.; Salgado, H.R. Gallic acid: Review of the methods of determination and quantification. Crit. Rev. Anal. Chem. 2016, 46, 257-265. [CrossRef] [PubMed]

27. Nayeem, N.; SMB, A.; Salem, H.; AHEl-Alfqy, S. Gallic acid: A promising lead molecule for drug development. J. Appl. Pharm. 2016, 8, 213. [CrossRef]

28. Kosuru, R.Y.; Roy, A.; Das, S.K.; Bera, S. Gallic acid and gallates in human health and disease: Do mitochondria hold the key to success? Mol. Nutr. Food Res. 2018, 62. [CrossRef]

29. Dludla, P.V.; Nkambule, B.B.; Dias, S.C.; Johnson, R. Cardioprotective potential of N-acetyl cysteine against hyperglycaemia-induced oxidative damage: A protocol for a systematic review. Syst. Rev. 2017, 6, 96. [CrossRef]

30. Weisberg, S.P.; McCann, D.; Desai, M.; Rosenbaum, M.; Leibel, R.L.; Ferrante, A.W., Jr. Obesity is associated with macrophage accumulation in adipose tissue. J. Clin. Investig. 2003, 112, 1796-1808. [CrossRef]

31. Cao, Y. Angiogenesis modulates adipogenesis and obesity. J. Clin. Investig. 2007, 117, 2362-2368. [CrossRef]

32. Ye, J. Adipose tissue vascularization: Its role in chronic inflammation. Curr. Diab. Rep. 2011, 11, $203-210$. [CrossRef] [PubMed]

33. Hausman, G.J.; Richardson, R.L. Adipose tissue angiogenesis. J. Anim. Sci. 2004, 82, 925-934. [CrossRef] [PubMed]

34. Cao, Y. Angiogenesis and vascular functions in modulation of obesity, adipose metabolism, and insulin sensitivity. Cell MeTable 2013, 18, 478-489. [CrossRef] [PubMed]

35. Sears, B.; Perry, M. The role of fatty acids in insulin resistance. Lipids Health Dis. 2015, 14, 121. [CrossRef] [PubMed]

36. Stolarczyk, E. Adipose tissue inflammation in obesity: A metabolic or immune response? Curr. Opin. Pharmacol. 2017, 37, 35-40. [CrossRef] [PubMed]

37. Hao, Z.; Münzberg, H.; Rezai-Zadeh, K.; Keenan, M.; Coulon, D.; Lu, H.; Berthoud, H.R.; Ye, J. Leptin deficient $\mathrm{ob} / \mathrm{ob}$ mice and diet-induced obese mice responded differently to Roux-en-Y bypass surgery. Int. J. Obes. 2015, 39, 798-805. [CrossRef] [PubMed]

38. Hotamisligil, G.S. Inflammation and metabolic disorders. Nature 2006, 444, 860-867. [CrossRef]

39. Katsuki, A.; Sumida, Y.; Murashima, S.; Murata, K.; Takarada, Y.; Ito, K.; Fujii, M.; Tsuchihashi, K.; Goto, H.; Nakatani, K.; et al. Serum levels of tumor necrosis factor-alpha are increased in obese patients with noninsulin-dependent diabetes mellitus. J. Clin. Endocrinol. MeTable 1998, 83, 859-862. [CrossRef]

40. Perego, L.; Pizzocri, P.; Corradi, D.; Maisano, F.; Paganelli, M.; Fiorina, P.; Barbieri, M.; Morabito, A.; Paolisso, G.; Folli, F.; et al. Circulating leptin correlates with left ventricular mass in morbid (grade III) obesity before and after weight loss induced by bariatric surgery: A potential role for leptin in mediating human left ventricular hypertrophy. J. Clin. Endocrinol. MeTable 2005, 90, 4087-4093. [CrossRef]

41. Dludla, P.V.; Essop, M.F.; Gabuza, K.B.; Muller, C.J.F.; Louw, J.; Johnson, R. Age-dependent development of left ventricular wall thickness in type 2 diabetic $(\mathrm{db} / \mathrm{db})$ mice is associated with elevated low-density lipoprotein and triglyceride serum levels. Heart Vessels 2017, 32, 1025-1031. [CrossRef]

42. Mangge, H.; Summers, K.L.; Meinitzer, A.; Zelzer, S.; Almer, G.; Prassl, R.; Schnedl, W.J.; Reininghaus, E.; Paulmichl, K.; Weghuber, D.; et al. Obesity-related dysregulation of the tryptophan-kynurenine metabolism: Role of age and parameters of the metabolic syndrome. Obesity 2014, 22, 195-201. [CrossRef] [PubMed]

43. Brandacher, G.; Hoeller, E.; Fuchs, D.; Weiss, H.G. Chronic immune activation underlies morbid obesity: Is IDO a key player? Curr. Drug MeTable 2007, 8, 289-295. [CrossRef]

44. Curat, C.A.; Wegner, V.; Sengenès, C.; Miranville, A.; Tonus, C.; Busse, R.; Bouloumié, A. Macrophages in human visceral adipose tissue: Increased accumulation in obesity and a source of resistin and visfatin. Diabetologia 2006, 49, 744-747. [CrossRef] [PubMed] 
45. Nio, Y.; Yamauchi, T.; Iwabu, M.; Okada-Iwabu, M.; Funata, M.; Yamaguchi, M.; Ueki, K.; Kadowaki, T. Monocyte chemoattractant protein-1 (MCP-1) deficiency enhances alternatively activated M2 macrophages and ameliorates insulin resistance and fatty liver in lipoatrophic diabetic A-ZIP transgenic mice. Diabetologia 2012, 55, 3350-3358. [CrossRef] [PubMed]

46. Furukawa, K.; Hori, M.; Ouchi, N.; Kihara, S.; Funahashi, T.; Matsuzawa, Y.; Miyazaki, A.; Nakayama, H.; Horiuchi, S. Adiponectin down-regulates acyl-coenzyme A: Cholesterol acyltransferase-1 in cultured human monocyte-derived macrophages. Biochem. Biophys. Res. Commun. 2004, 317, 831-836. [CrossRef] [PubMed]

47. Ehsan, M.; Singh, K.K.; Lovren, F.; Pan, Y.; Quan, A.; Mantella, L.E.; Sandhu, P.; Teoh, H.; Al-Omran, M.; Verma, S. Adiponectin limits monocytic microparticle-induced endothelial activation by modulation of the AMPK, Akt and NFkappaB signaling pathways. Atherosclerosis 2016, 245, 1-11. [CrossRef] [PubMed]

48. Saucillo, D.C.; Gerriets, V.A.; Sheng, J.; Rathmell, J.C.; Maciver, N.J. Leptin metabolically licenses T cells for activation to link nutrition and immunity. J. Immunol. 2014, 192, 136-144. [CrossRef]

49. Ip, B.; Cilfone, N.A.; Belkina, A.C.; DeFuria, J.; Jagannathan-Bogdan, M.; Zhu, M.; Kuchibhatla, R.; McDonnell, M.E.; Xiao, Q.; Kepler, T.B.; et al. Th17 cytokines differentiate obesity from obesity-associated type 2 diabetes and promote TNFalpha production. Obesity 2016, 24, 102-112. [CrossRef]

50. Gonzalez, Y.; Herrera, M.T.; Soldevila, G.; Garcia-Garcia, L.; Fabián, G.; Pérez-Armendariz, E.M.; Bobadilla, K.; Guzmán-Beltrán, S.; Sada, E.; Torres, M. High glucose concentrations induce TNF-alpha production through the down-regulation of CD33 in primary human monocytes. BMC Immunol. 2012, 13, 19. [CrossRef]

51. Lajaunias, F.; Dayer, J.M.; Chizzolini, C. Constitutive repressor activity of CD33 on human monocytes requires sialic acid recognition and phosphoinositide 3-kinase-mediated intracellular signaling. Eur. J. Immunol. 2005, 35, 243-251. [CrossRef]

52. Jin, W.; Dong, C. IL-17 cytokines in immunity and inflammation. Emerg. Microbes. Infect. 2013, 2, e60. [CrossRef] [PubMed]

53. Capurso, C.; Capurso, A. From excess adiposity to insulin resistance: The role of free fatty acids. Vascul. Pharmacol. 2012, 57, 91-97. [CrossRef] [PubMed]

54. Johnson, R.; Dludla, P.V.; Muller, C.J.; Huisamen, B.; Essop, M.F.; Louw, J. The transcription profile unveils the cardioprotective effect of aspalathin against lipid toxicity in an in vitro H9c2 model. Molecules 2017, 22, 22. [CrossRef] [PubMed]

55. Glass, C.K.; Olefsky, J.M. Inflammation and lipid signaling in the etiology of insulin resistance. Cell MeTable 2012, 15, 635-645. [CrossRef] [PubMed]

56. Johnson, A.M.; Olefsky, J.M. The origins and drivers of insulin resistance. Cell 2013, 152, 673-684. [CrossRef]

57. Soskic, S.S.; Dobutović, B.D.; Sudar, E.M.; Obradović, M.M.; Nikolić, D.M.; Djordjevic, J.D.; Radak, D.J.; Mikhailidis, D.P.; Isenović, E.R. Regulation of inducible nitric oxide synthase (iNOS) and its potential role in insulin resistance, diabetes and heart failure. Open Cardiovasc. Med. J. 2011, 5, 153-163. [CrossRef] [PubMed]

58. Yasukawa, T.; Tokunaga, E.; Ota, H.; Sugita, H.; Martyn, J.A.; Kaneki, M. S-nitrosylation-dependent inactivation of Akt/protein kinase B in insulin resistance. J. Biol. Chem. 2005, 280, 7511-7518. [CrossRef]

59. Kaneto, H.; Xu, G.; Fujii, N.; Kim, S.; Bonner-Weir, S.; Weir, G.C. Involvement of c-Jun N-terminal kinase in oxidative stress-mediated suppression of insulin gene expression. J. Biol. Chem. 2002, 277, 30010-30018. [CrossRef]

60. Manna, P.; Jain, S.K. Obesity, oxidative Stress, adipose tissue dysfunction, and the associated health risks: Causes and therapeutic strategies. Metab. Syndr. Relat. Disord. 2015, 13, 423-444. [CrossRef]

61. Hajjar, D.P.; Gotto, A.M., Jr. Biological relevance of inflammation and oxidative stress in the pathogenesis of arterial diseases. Am. J. Pathol. 2013, 182, 1474-1481. [CrossRef]

62. Sies, H. Oxidative stress: A concept in redox biology and medicine. Redox Biol. 2015, 4, 180-183. [CrossRef] [PubMed]

63. Dludla, P.V.; Joubert, E.; Muller, C.J.F.; Louw, J.; Johnson, R. Hyperglycemia-induced oxidative stress and heart disease-cardioprotective effects of rooibos flavonoids and phenylpyruvic acid-2-O-beta-D-glucoside. Nutr. MeTable 2017, 14, 45. [CrossRef] [PubMed]

64. Han, C.Y. Roles of reactive oxygen species on insulin resistance in adipose tissue. Diabetes Metab. J. 2016, 40, 272-279. [CrossRef] [PubMed] 
65. Jankovic, A.; Korac, A.; Buzadzic, B.; Otasevic, V.; Stancic, A.; Daiber, A.; Korac, B. Redox implications in adipose tissue (dys)function-A new look at old acquaintances. Redox Biol. 2015, 6, 19-32. [CrossRef] [PubMed]

66. Furukawa, S.; Fujita, T.; Shimabukuro, M.; Iwaki, M.; Yamada, Y.; Nakajima, Y.; Nakayama, O.; Makishima, M.; Matsuda, M.; Shimomura, I. Increased oxidative stress in obesity and its impact on metabolic syndrome. J. Clin. Investig. 2004, 114, 1752-1761. [CrossRef]

67. Den Hartigh, L.J.; Omer, M.; Goodspeed, L.; Wang, S.; Wietecha, T.; O’Brien, K.D.; Han, C.Y. Adipocyte-specific deficiency of NADPH oxidase 4 delays the onset of insulin resistance and attenuates adipose tissue inflammation in obesity. Arterioscler. Thromb. Vasc. Biol. 2017, 37, 466-475. [CrossRef] [PubMed]

68. Han, C.Y.; Umemoto, T.; Omer, M.; Den Hartigh, L.J.; Chiba, T.; LeBoeuf, R.; Buller, C.L.; Sweet, I.R.; Pennathur, S.; Abel, E.D.; et al. NADPH oxidase-derived reactive oxygen species increases expression of monocyte chemotactic factor genes in cultured adipocytes. J. Biol. Chem. 2012, 287, 10379-10393. [CrossRef]

69. Murphy, M.P. How mitochondria produce reactive oxygen species. Biochem. J. 2009, 417, 1-13. [CrossRef]

70. Dludla, P.V.; Nkambule, N.B.; Tiano, L.; Louw, J.; Jastroch, M.; Mazibuko-Mbeje, S.E. Uncoupling proteins as a therapeutic target to protect the diabetic heart. Pharmacol. Res. 2018, 137, 11-24. [CrossRef]

71. Hurrle, S.; Hsu, W.H. The etiology of oxidative stress in insulin resistance. Biomed. J. 2017, 40, $257-262$. [CrossRef]

72. De Marchi, E.; Baldassari, F.; Bononi, A.; Wieckowski, M.R.; Pinton, P. Oxidative stress in cardiovascular diseases and obesity: Role of p66Shc and protein kinase C. Oxid. Med. Cell. Longev. 2013, 2013, 564961. [CrossRef] [PubMed]

73. Amiot, M.J.; Riva, C.; Vinet, A. Effects of dietary polyphenols on metabolic syndrome features in humans: A systematic review. Obes. Rev. 2016, 17, 573-586. [CrossRef] [PubMed]

74. Gregorio, B.M.; De Souza, D.B.; de Morais Nascimento, F.A.; Pereira, L.M.; Fernandes-Santos, C. The potential role of antioxidants in metabolic syndrome. Curr. Pharm. Des. 2016, 22, 859-869. [CrossRef]

75. Jack, B.U.; Malherbe, C.J.; Willenburg, E.L.; de Beer, D.; Huisamen, B.; Joubert, E.; Muller, C.J.F.; Louw, J.; Pheiffer, C. Polyphenol-enriched fractions of Cyclopia intermedia selectively affect lipogenesis and lipolysis in 3T3-L1 adipocytes. Planta Med. 2018, 84, 100-110. [CrossRef] [PubMed]

76. Pollack, R.M.; Donath, M.Y.; LeRoith, D.; Leibowitz, G. Anti-inflammatory agents in the treatment of diabetes and its vascular complications. Diabetes Care 2016, 39, S244-S252. [CrossRef] [PubMed]

77. National Center for Biotechnology Information: PubChem CID: 370. Available online: https://pubchem. ncbi.nlm.nih.gov/compound/Gallic_acid (accessed on 9 August 2018).

78. Nabavi, S.F.; Habtemariam, S.; Di Lorenzo, A.; Sureda, A.; Khanjani, S.; Nabavi, S.M.; Daglia, M. Post-stroke depression modulation and in vivo antioxidant activity of gallic acid and its synthetic derivatives in a murine model system. Nutrients 2016, 8, 248. [CrossRef] [PubMed]

79. National Center for Biotechnology Information: PubChem CID: 245086. Available online: https://pubchem. ncbi.nlm.nih.gov/substance/24724290 (accessed on 9 August 2018).

80. National Center for Biotechnology Information: PubChem CID: 13250. Available online: https://pubchem. ncbi.nlm.nih.gov / compound/ethyl_gallate (accessed on 9 August 2018).

81. National Center for Biotechnology Information: PubChem CID: 199472. Available online: https://pubchem. ncbi.nlm.nih.gov / compound/Gallocatechin_gallate (accessed on 9 August 2018).

82. National Center for Biotechnology Information: PubChem CID: 7428. Available online: https://pubchem. ncbi.nlm.nih.gov/compound/7428 (accessed on 9 August 2018).

83. National Center for Biotechnology Information: PubChem CID: 4947. Available online: https://pubchem. ncbi.nlm.nih.gov/compound/propyl_gallate (accessed on 9 August 2018).

84. National Center for Biotechnology Information: PubChem CID: 169167. Available online: https://pubchem. ncbi.nlm.nih.gov/compound/169167 (accessed on 9 August 2018).

85. Karakaya, S. Bioavailability of phenolic compounds. Crit. Rev. Food Sci. Nutr. 2004, 44, 453-464. [CrossRef] [PubMed]

86. Ma, F.W.; Deng, Q.F.; Zhou, X.; Gong, X.J.; Zhao, Y.; Chen, H.G.; Zhao, C. The tissue distribution and urinary excretion study of gallic acid and protocatechuic acid after oral administration of Polygonum aapitatum extract in rats. Molecules 2016, 21, 399. [CrossRef] 
87. Athukuri, B.L.; Neerati, P. Enhanced oral bioavailability of diltiazem by the influence of gallic acid and ellagic acid in male Wistar rats: Involvement of CYP3A and P-gp inhibition. Phytother. Res. 2017, 31, 1441-1448. [CrossRef]

88. Shahrzad, S.; Aoyagi, K.; Winter, A.; Koyama, A.; Bitsch, I. Pharmacokinetics of gallic acid and its relative bioavailability from tea in healthy humans. J. Nutr. 2001, 131, 1207-1210. [CrossRef]

89. Konishi, Y.; Hitomi, Y.; Yoshioka, E. Intestinal absorption of p-coumaric and gallic acids in rats after oral administration. J. Agric. Food Chem. 2004, 52, 2527-2532. [CrossRef] [PubMed]

90. Daglia, M.; Di Lorenzo, A.; Nabavi, S.F.; Talas, Z.S.; Nabavi, S.M. Polyphenols: Well beyond the antioxidant capacity: Gallic acid and related compounds as neuroprotective agents: You are what you eat! Curr. Pharm. Biotechnol. 2014, 15, 362-372. [CrossRef] [PubMed]

91. Ferruzzi, M.G.; Lobo, J.K.; Janle, E.M.; Cooper, B.; Simon, J.E.; Wu, Q.L.; Welch, C.; Ho, L.; Weaver, C.; Pasinetti, G.M. Bioavailability of gallic acid and catechins from grape seed polyphenol extract is improved by repeated dosing in rats: Implications for treatment in Alzheimer's disease. J. Alzheimers Dis. 2009, 18, 113-124. [CrossRef] [PubMed]

92. Bhattacharyya, S.; Ahammed, S.M.; Saha, B.P.; Mukherjee, P.K. The gallic acid-phospholipid complex improved the antioxidant potential of gallic acid by enhancing its bioavailability. AAPS Pharm. Sci. Tech. 2013, 14, 1025-1033. [CrossRef] [PubMed]

93. Yu, Z.; Song, F.; Jin, Y.C.; Zhang, W.M.; Zhang, Y.; Liu, E.J.; Zhou, D.; Bi, L.L.; Yang, Q.; Li, H.; et al. Comparative pharmacokinetics of gallic acid after oral administration of gallic acid monohydrate in normal and isoproterenol-induced myocardial infarcted rats. Front. Pharmacol. 2018, 9, 328. [CrossRef] [PubMed]

94. Lutz, T.A.; Woods, S.C. Overview of animal models of obesity. Curr. Protoc. Pharmacol. 2012. [CrossRef]

95. Oi, Y.; Hou, I.C.; Fujita, H.; Yazawa, K. Antiobesity effects of Chinese black tea (Pu-erh tea) extract and gallic acid. Phytother. Res. 2012, 26, 475-481. [CrossRef]

96. Hsu, C.L.; Yen, G.C. Effects of flavonoids and phenolic acids on the inhibition of adipogenesis in 3T3-L1 adipocytes. J. Agric. Food Chem. 2007, 55, 8404-8410. [CrossRef]

97. Hsieh, C.F.; Tsuei, Y.W.; Liu, C.W.; Kao, C.C.; Shih, L.J.; Ho, L.T.; Wu, L.Y.; Wu, C.P.; Tsai, P.H.; Chang, H.H. Green tea epigallocatechin gallate inhibits insulin stimulation of adipocyte glucose uptake via the 67-kilodalton laminin receptor and AMP-activated protein kinase pathways. Planta Med. 2010, 76, 1694-1698. [CrossRef]

98. Makihara, H.; Shimada, T.; Machida, E.; Oota, M.; Nagamine, R.; Tsubata, M.; Kinoshita, K.; Takahashi, K.; Aburada, M. Preventive effect of Terminalia bellirica on obesity and metabolic disorders in spontaneously obese type 2 diabetic model mice. J. Nat. Med. 2012, 66, 459-467. [CrossRef]

99. Yuda, N.; Tanaka, M.; Suzuki, M.; Asano, Y.; Ochi, H.; Iwatsuki, K. Polyphenols extracted from black tea (Camellia sinensis) residue by hot-compressed water and their inhibitory effect on pancreatic lipase in vitro. J. Food Sci. 2012, 77, H254-H261. [CrossRef] [PubMed]

100. De la Garza, A.L.; Milagro, F.I.; Boque, N.; Campión, J.; Martínez, J.A. Natural inhibitors of pancreatic lipase as new players in obesity treatment. Planta Med. 2011, 77,773-785. [CrossRef] [PubMed]

101. Zengin, G.; Uysal, A.; Aktumsek, A.; Mocan, A.; Mollica, A.; Locatelli, M.; Custodio, L.; Neng, N.R.; Nogueira, J.M.F.; Aumeeruddy-Elalfi, Z.; et al. Euphorbia denticulata Lam.: A promising source of phyto-pharmaceuticals for the development of novel functional formulations. Biomed. Pharmacother. 2017, 87, 27-36. [CrossRef] [PubMed]

102. Chang, P.C.; Wang, J.D.; Lee, M.M.; Chang, S.S.; Tsai, T.Y.; Chang, K.W.; Tsai, F.J.; Chen, C.Y. Lose weight with traditional chinese medicine? Potential suppression of fat mass and obesity-associated protein. J. Biomol. Struct. Dyn. 2011, 29, 471-483. [CrossRef]

103. Strobel, P.; Allard, C.; Perez-Acle, T.; Calderon, R.; Aldunate, R.; Leighton, F. Myricetin, quercetin and catechin-gallate inhibit glucose uptake in isolated rat adipocytes. Biochem. J. 2005, 386, 471-478. [CrossRef] [PubMed]

104. Hsu, C.L.; Huang, S.L.; Yen, G.C. Inhibitory effect of phenolic acids on the proliferation of 3T3-L1 preadipocytes in relation to their antioxidant activity. J. Agric. Food Chem. 2006, 54, 4191-4197. [CrossRef]

105. Hsu, C.L.; Yen, G.C. Effect of gallic acid on high fat diet-induced dyslipidaemia, hepatosteatosis and oxidative stress in rats. Br. J. Nutr. 2007, 98, 727-735. [CrossRef] 
106. Jang, A.; Srinivasan, P.; Lee, N.Y.; Song, H.P.; Lee, J.W.; Lee, M.; Jo, C. Comparison of hypolipidemic activity of synthetic gallic acid-linoleic acid ester with mixture of gallic acid and linoleic acid, gallic acid, and linoleic acid on high-fat diet induced obesity in C57BL/6 Cr Slc mice. Chem. Biol. Interact. 2008, 174, 109-117. [CrossRef]

107. Booth, A.; Amen, R.J.; Scott, M.; Greenway, F.L. Oral dose-ranging developmental toxicity study of an herbal supplement (NT) and gallic acid in rats. Adv. Ther. 2010, 27, 250-255. [CrossRef]

108. Punithavathi, V.R.; Stanely Mainzen Prince, P.; Kumar, M.R.; Selvakumari, C.J. Protective effects of gallic acid on hepatic lipid peroxide metabolism, glycoprotein components and lipids in streptozotocin-induced type II diabetic Wistar rats. J. Biochem. Mol. Toxicol. 2011, 25, 68-76. [CrossRef]

109. Bak, E.J.; Kim, J.; Jang, S.; Woo, G.H.; Yoon, H.G.; Yoo, Y.J.; Cha, J.H. Gallic acid improves glucose tolerance and triglyceride concentration in diet-induced obesity mice. Scand. J. Clin. Lab. Investig. 2013, 73, 607-614. [CrossRef] [PubMed]

110. Ou, T.T.; Lin, M.C.; Wu, C.H.; Lin, W.L.; Wang, C.J. Gallic acid attenuates oleic acid-induced proliferation of vascular smooth muscle cell through regulation of AMPK-eNOS-FAS signaling. Curr. Med. Chem. 2013, 20, 3944-3953. [CrossRef] [PubMed]

111. Doan, K.V.; Ko, C.M.; Kinyua, A.W.; Yang, D.J.; Choi, Y.H.; Oh, I.Y.; Nguyen, N.M.; Ko, A.; Choi, J.W.; Jeong, Y. Gallic acid regulates body weight and glucose homeostasis through AMPK activation. Endocrinology 2015, 156, 157-168. [CrossRef] [PubMed]

112. Huang, D.W.; Chang, W.C.; Yang, H.J.; Wu, J.S.; Shen, S.C. Gallic acid alleviates hypertriglyceridemia and fat accumulation via modulating glycolysis and lipolysis pathways in perirenal adipose tissues of rats fed a high-fructose diet. Int. J. Mol. Sci. 2018, 19, 254. [CrossRef] [PubMed]

113. Ong, K.C.; Khoo, H.E.; Das, N.P. Tannic acid inhibits insulin-stimulated lipogenesis in rat adipose tissue and insulin receptor function in vitro. Experientia 1995, 51, 577-584. [CrossRef]

114. Ren, Y.; Himmeldirk, K.; Chen, X. Synthesis and structure-activity relationship study of antidiabetic penta-O-galloyl-D-glucopyranose and its analogues. J. Med. Chem. 2006, 49, 2829-2837. [CrossRef] [PubMed]

115. Sergent, T.V.J.; Winand, J.; Beguin, P.; Schneider, Y.J. Phenolic compounds and plant extracts as potential natural anti-obesity substances. Food Chem. 2012, 135, 68-73. [CrossRef]

116. Park, Y.K.; Lee, J.; Hong, V.S.; Choi, J.S.; Lee, T.Y.; Jang, B.C. Identification of KMU-3, a novel derivative of gallic acid, as an inhibitor of adipogenesis. PLoS ONE 2014, 9, e109344. [CrossRef]

117. Yang, Y.; Qiao, L.; Zhang, X.; Wu, Z.; Weng, P. Effect of methylated tea catechins from Chinese oolong tea on the proliferation and differentiation of 3T3-L1 preadipocyte. Fitoterapia 2015, 104, 45-49. [CrossRef]

118. Jeon, M.; Rahman, N.; Kim, Y.S. Wnt/beta-catenin signaling plays a distinct role in methyl gallate-mediated inhibition of adipogenesis. Biochem. Biophys. Res. Commun. 2016, 479, 22-27. [CrossRef]

119. Amin, K.A.; Nagy, M.A. Effect of Carnitine and herbal mixture extract on obesity induced by high fat diet in rats. Diabetol. Metab. Syndr. 2009, 1, 17. [CrossRef] [PubMed]

120. Hogan, S.; Canning, C.; Sun, S.; Sun, X.; Zhou, K. Effects of grape pomace antioxidant extract on oxidative stress and inflammation in diet induced obese mice. J. Agric. Food Chem. 2010, 58, 11250-11256. [CrossRef]

121. Cao, Z.H.; Gu, D.H.; Lin, Q.Y.; Xu, Z.Q.; Huang, Q.C.; Rao, H.; Liu, E.W.; Jia, J.J.; Ge, C.R. Effect of pu-erh tea on body fat and lipid profiles in rats with diet-induced obesity. Phytother. Res. 2011, 25, 234-238. [CrossRef] [PubMed]

122. Koh, G.Y.; McCutcheon, K.; Zhang, F.; Liu, D.; Cartwright, C.A.; Martin, R.; Yang, P.; Liu, Z. Improvement of obesity phenotype by Chinese sweet leaf tea (Rubus suavissimus) components in high-fat diet-induced obese rats. J. Agric. Food Chem. 2011, 59, 98-104. [CrossRef] [PubMed]

123. Peng, C.H.; Liu, L.K.; Chuang, C.M.; Chyau, C.C.; Huang, C.N.; Wang, C.J. Mulberry water extracts possess an anti-obesity effect and ability to inhibit hepatic lipogenesis and promote lipolysis. J. Agric. Food Chem. 2011, 59, 2663-2671. [CrossRef] [PubMed]

124. Monika, P.; Geetha, A. The modulating effect of Persea americana fruit extract on the level of expression of fatty acid synthase complex, lipoprotein lipase, fibroblast growth factor-21 and leptin-A biochemical study in rats subjected to experimental hyperlipidemia and obesity. Phytomedicine 2015, 22, 939-945. [CrossRef] [PubMed]

125. Colantuono, A.; Ferracane, R.; Vitaglione, P. In vitro bioaccessibility and functional properties of polyphenols from pomegranate peels and pomegranate peels-enriched cookies. Food Funct. 2016, 7, 4247-4258. [CrossRef] 
126. de Camargo, A.C.; Regitano-d'Arce, M.A.; Biasoto, A.C.; Shahidi, F. Enzyme-assisted extraction of phenolics from winemaking by-products: Antioxidant potential and inhibition of alpha-glucosidase and lipase activities. Food Chem. 2016, 212, 395-402. [CrossRef]

127. Park, B.; Lee, S.; Lee, B.; Kim, I.; Baek, N.; Lee, T.H.; Lee, S.Y.; Son, M.; Park, H. New ethanol extraction improves the anti-obesity effects of black tea. Arch. Pharm. Res. 2016, 39, 310-320. [CrossRef]

128. Septembre-Malaterre, A.; Stanislas, G.; Douraguia, E.; Gonthier, M.P. Evaluation of nutritional and antioxidant properties of the tropical fruits banana, litchi, mango, papaya, passion fruit and pineapple cultivated in Reunion French Island. Food Chem. 2016, 212, 225-233. [CrossRef]

129. Torabi, S.; DiMarco, N.M. Polyphenols extracted from grape powder induce lipogenesis and glucose uptake during differentiation of murine preadipocytes. Exp. Biol. Med. 2016, 241, 1776-1785. [CrossRef] [PubMed]

130. Pascual-Serrano, A.; Arola-Arnal, A.; Suárez-García, S.; Bravo, F.I.; Suárez, M.; Arola, L.; Bladé, C. Grape seed proanthocyanidin supplementation reduces adipocyte size and increases adipocyte number in obese rats. Int. J. Obes. 2017, 41, 1246-1255. [CrossRef] [PubMed]

131. Simao, A.A.; Marques, T.R.; Marcussi, S.; Corrêa, A.D. Aqueous extract of Psidium guajava leaves: Phenolic compounds and inhibitory potential on digestive enzymes. An. Acad. Bras. Cienc. 2017, 89, 2155-2165. [CrossRef] [PubMed]

132. Ge, Q.; Chen, L.; Tang, M.; Zhang, S.; Liu, L.; Gao, L. Analysis of mulberry leaf components in the treatment of diabetes using network pharmacology. Eur. J. Pharmacol. 2018, 833, 50-62. [CrossRef]

133. Sandoval-Gallegos, E.M.; Ramírez-Moreno, E.; Lucio, J.G.; Arias-Rico, J.; Cruz-Cansino, N.; Ortiz, M.I.; Cariño-Cortés, R. In vitro bioaccessibility and effect of Mangifera indica (Ataulfo) leaf extract on induced dyslipidemia. J. Med. Food 2018, 21, 47-56. [CrossRef]

134. Wu, S.; Tian, L. A new flavone glucoside together with known ellagitannins and flavones with anti-diabetic and anti-obesity activities from the flowers of pomegranate (Punica granatum). Nat. Prod. Res. 2018, 1-6. [CrossRef] [PubMed]

135. Wu, C.H.; Yang, M.Y.; Chan, K.C.; Chung, P.J.; Ou, T.T.; Wang, C.J. Improvement in high-fat diet-induced obesity and body fat accumulation by a Nelumbo nucifera leaf flavonoid-rich extract in mice. J. Agric. Food Chem. 2010, 58, 7075-7081. [CrossRef]

136. Batista, A.G.; Lenquiste, S.A.; Cazarin, C.B.B.; da Silva, J.K.; Luiz-Ferreira, A.; Bogusz, S., Jr.; Hantao, L.W.; de Souza, R.N.; Augusto, F.; Prado, M.A.; et al. Intake of jaboticaba peel attenuates oxidative stress in tissues and reduces circulating saturated lipids of rats with high-fat diet-induced obesity. J. Funct. Foods 2014, 6, 450-461. [CrossRef]

137. Foddai, M.; Kasabri, V.; Petretto, G.L.; Azara, E.; Sias, A.; Afifi, F.U. In vitro inhibitory effects of Limonium contortirameum and L. virgatum extracts from sardinia on alpha-amylase, alpha-glucosidase and pancreatic lipase. Nat. Prod. Commun. 2014, 9, 181-184.

138. Irondi, E.A.; Agboola, S.O.; Oboh, G.; Boligon, A.A. Inhibitory effect of leaves extracts of Ocimum basilicum and Ocimum gratissimum on two key enzymes involved in obesity and hypertension in vitro. J. Intercult. Ethnopharmacol. 2016, 5, 396-402. [CrossRef]

139. Abeysekera, W.; Arachchige, S.P.G. Bark extracts of Ceylon cinnamon possess antilipidemic activities and bind bile acids in vitro. Evid. Based Complement. Alternat. 2017, 2017, 7347219. [CrossRef]

140. Bayes, W. Gallic acid in haemoptysis. Prov. Med. Surg. J. 1852, 16, 498-499. [CrossRef] [PubMed]

141. Roberts, A.T. Gallic Acid: Inhibiting Angiogenesis in Adipose Tissue. Master's Thesis, Louisiana State University and Agricultural and Mechanical College, Barton Rouge, LA, USA, 2006. Available online: https:/ / digitalcommons.lsu.edu/gradschool_theses/1261/ (accessed on 12 August 2018).

142. Greenway, F.L.; Liu, Z.; Martin, C.K.; Kai-yuan, W.; Nofziger, J.; Rood, J.C. Safety and efficacy of NT, an herbal supplement, in treating human obesity. Int. J. Obes. 2006, 30, 1737-1741. [CrossRef] [PubMed]

143. Heber, D.; Seeram, N.P.; Wyatt, H.; Henning, S.M.; Zhang, Y.; Ogden, L.G.; Dreher, M.; Hill, J.O. Safety and antioxidant activity of a pomegranate ellagitannin-enriched polyphenol dietary supplement in overweight individuals with increased waist size. J. Agric. Food Chem. 2007, 55, 10050-10054. [CrossRef] [PubMed]

144. Skrzypczak-Jankun, E.; Jankun, J. Theaflavin digallate inactivates plasminogen activator inhibitor: Could tea help in Alzheimer's disease and obesity? Int. J. Mol. Med. 2010, 26, 45-50. [PubMed]

145. Kubota, K.; Sumi, S.; Tojo, H.; Sumi-Inoue, Y.; I-Chin, H.; Oi, Y.; Fujita, H.; Urata, H. Improvements of mean body mass index and body weight in preobese and overweight Japanese adults with black Chinese tea (Pu-Erh) water extract. Nutr. Res. 2011, 31, 421-428. [CrossRef] 
146. Hernandez, J.R.; Rizzo, J.F.; Díaz, Y.C.; Bubi, E.D.; Cabrillana, J.M.; López-Tomassetti Fernández, E.M. Effect of bismuth subgallate on the quality of life in patients undergoing Scopinaro's biliopancreatic diversion. Surg. Obes. Relat. Dis. 2015, 11, 436-441. [CrossRef]

147. Wang, C.; Shi, C.; Yang, X.; Yang, M.; Sun, H.; Wang, C. Celastrol suppresses obesity process via increasing antioxidant capacity and improving lipid metabolism. Eur. J. Pharmacol. 2014, 744, 52-58. [CrossRef]

148. Wang, S.; Liang, X.; Yang, Q.; Fu, X.; Rogers, C.J.; Zhu, M. Resveratrol induces brown-like adipocyte formation in white fat through activation of AMP-activated protein kinase (AMPK) alpha1. Int. J. Obes. 2015, 39, 967-976. [CrossRef]

149. Yang, C.S.; Zhang, J.; Zhang, L.; Huang, J.; Wang, Y. Mechanisms of body weight reduction and metabolic syndrome alleviation by tea. Mol. Nutr. Food Res. 2016, 60, 160-174. [CrossRef]

150. Graham, H.N. Green tea composition, consumption, and polyphenol chemistry. Prev. Med. 1992, 21, 334-350. [CrossRef]

151. Lin, J.K.; Lin, L.C.; Liang, Y.C.; Lin-Shiau, S.Y.; Juan, I.M. Survey of catechins, gallic acid, and methylxanthines in green, oolong, Pu-erh, and black teas. J. Agric. Food Chem. 1998, 46, 3635-3642. [CrossRef]

152. Wolfram, S.; Wang, Y.; Thielecke, F. Anti-obesity effects of green tea: From bedside to bench. Mol. Nutr. Food Res. 2006, 50, 176-187. [CrossRef]

153. Butler, M.S.; Robertson, A.A.; Cooper, M.A. Natural product and natural product derived drugs in clinical trials. Nat. Prod. Rep. 2014, 31, 1612-1661. [CrossRef] [PubMed]

154. Paller, C.J.; Denmeade, S.R.; Carducci, M.A. Challenges of conducting clinical trials of natural products to combat cancer. Clin. Adv. Hematol. Oncol. 2016, 14, 447-455.

155. Patel, O.; Muller, C.; Joubert, E.; Louw, J.; Rosenkranz, B.; Awortwe, C. Inhibitory interactions of Aspalathus linearis (rooibos) extracts and compounds, aspalathin and Z-2-(beta-d-glucopyranosyloxy)3-phenylpropenoic acid, on cytochromes metabolizing hypoglycemic and hypolipidemic drugs. Molecules 2016, 21, 1515. [CrossRef]

156. Liu, Y.; Sun, M.; Yao, H.; Liu, Y.; Gao, R. Herbal medicine for the treatment of obesity: An overview of scientific evidence from 2007 to 2017. Evid. Based Complement. Alternat. Med. 2017, 2017, 8943059. [CrossRef]

157. Awortwe, C.; Makiwane, M.; Reuter, H.; Muller, C.; Louw, J.; Rosenkranz, B. Critical evaluation of causality assessment of herb-drug interactions in patients. Br. J. Clin. Pharmacol. 2018, 84, 679-693. [CrossRef]

158. Wang, S.; Zhu, M.J.; Du, M. Prevention of obesity by dietary resveratrol: How strong is the evidence? Expert. Rev. Endocrinol. MeTable 2015, 10, 561-564. [CrossRef]

159. Christenson, J.; Whitby, S.J.; Mellor, D.; Thomas, J.; McKune, A.; Roach, P.D. The effects of resveratrol supplementation in overweight and obese humans: A Systematic review of randomized trials. Metab. Syndr. Relat. Disord. 2016, 14, 323-333. [CrossRef]

160. Fu, C.; Jiang, Y.; Guo, J.; Su, Z. Natural products with anti-obesity effects and different mechanisms of action. J. Agric. Food Chem. 2016, 9571-9585. [CrossRef] [PubMed]

161. Deng, H.; Fang, Y. Anti-inflammatory gallic acid and wedelolactone are G protein-coupled receptor-35 agonists. Pharmacology 2012, 89, 211-219. [CrossRef] [PubMed]

(C) 2018 by the authors. Licensee MDPI, Basel, Switzerland. This article is an open access article distributed under the terms and conditions of the Creative Commons Attribution (CC BY) license (http:// creativecommons.org/licenses/by/4.0/). 